\title{
ASPECTOS CONSTRUCTIVOS Y DECORATIVOS DE LA VILLA ROMANA DE PUENTE DE LA OLMILLA (ALBALADEJO, CIUDAD REAL)
}

\author{
CONSTRUCTIVE AND ORNAMENTAL FEATURES OF THE ROMAN VILLA IN PUENTE DE \\ LA OLMILLA (ALBALADEJO, CIUDAD REAL)
}

\section{EL MARCO GEOGRÁFICO}

La villa de Puente de la Olmilla se halla en el término municipal de Albaladejo, en el extremo suroriental

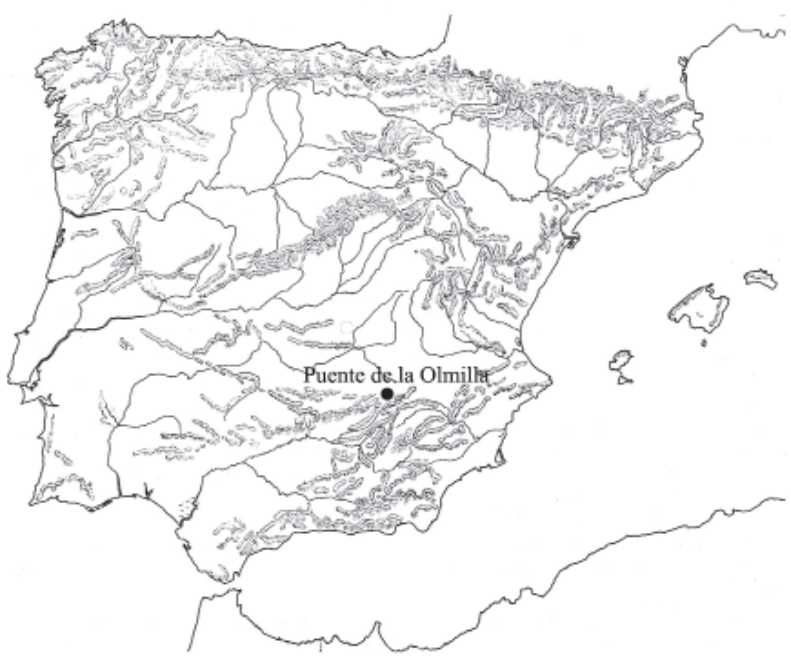

Figura 1: Localización de la villa de Puente de la Olmilla.

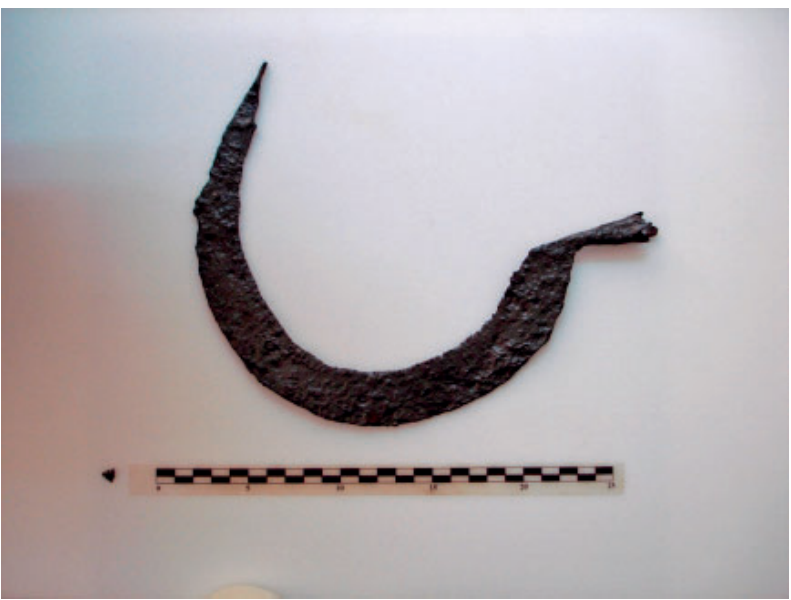

Figura 2: Hoz. Foto: Racionero Núñez (MP de Ciudad Real).
CARMEN GARCÍA BUENO

de la provincia de Ciudad Real, colindando con las de Jaén y Albacete (Fig. 1). Se trata de una altiplanicie fuertemente basculada de Este a Oeste, que se encuentra en la confluencia de Sierra Morena y la Sierra de Alcaraz, emergentes en la parte meridional del Campo de Montiel. Algo más lejos está la Sierra de Segura. En la zona septentrional presenta una accidentada topografía, con algunos montes de escasa altitud, mientras que la restante es llana, con valles cultivables, entre ellos, el que acoge a la villa. Desde ésta se puede divisar un horizonte de montañas constituido por los perfiles serranos de Alcaraz y del Relumbrar, que enlazan con la Sierra de Villanueva de la Fuente, si bien predomina la planicie en el paisaje circundante, con suaves lomas y alguna otra pequeña elevación orográfica.

La actividad agrícola llevada a cabo en este complejo rural queda perfectamente contrastada a través del hallazgo de algunos útiles metálicos y líticos, p. ej., una hoz, un fragmento de otra, lascas de sílex tallado, pertenecientes a una posible hoz o trillo, etc. (Fig. 2).

La red de drenaje pertenece a la cuenca del Guadalquivir. Atraviesa este término municipal el río Guadalmena, además de algunos otros arroyos como el de La Comendaora o el de la Fuente de la Bola, muy próximo al anterior, que surca el paraje de Puente de la Olmilla. Sobre la ribera izquierda de este último arroyuelo fue erigida la villa romana objeto de nuestra atención. Estos últimos cursos de agua son su fuente más obvia de aprovisionamiento y fueron de crucial importancia para hacer viable un establecimiento basado en una economía agro-pastoril, con toda probabilidad dedicado fundamentalmente al cultivo cerealístico y olivarero (han aparecido fragmentos de dolia para almacenar grano, vino y aceite). La fácil disponibilidad de este preciado recurso ${ }^{1}$, indispensable para cualquier asentamiento humano, condicionó con toda

1. Principio básico según Varrón (rust. I, 11,2), Catón (agr. I, 1,3) o Columela (De r.r. I, 5, 1-2). 


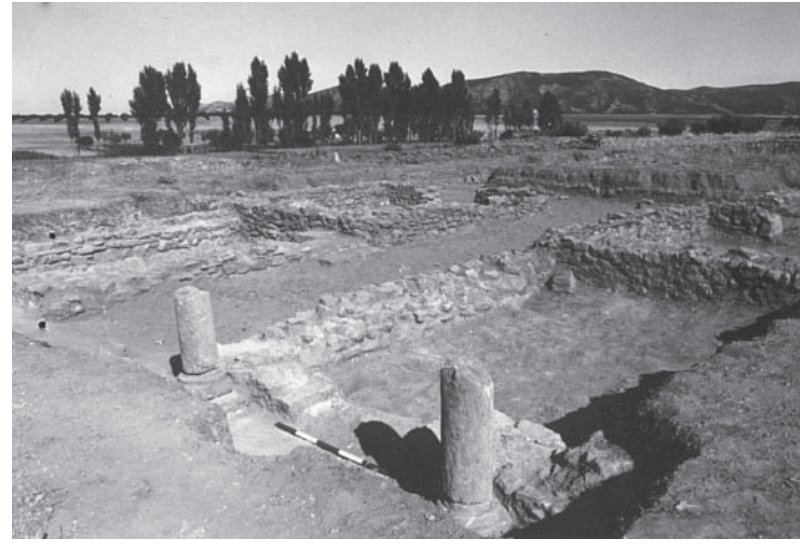

Figura 3: Habitación n. ${ }^{\circ}$ 22, con columnas in situ, y vista general del yacimiento, junto a un arroyo, en cuya margen crece abundante vegetación. Foto: Puig y Montanya (AGA).

seguridad la elección del emplazamiento de éste (Fig. $3)$. Esos manantiales y el ameno panorama contribuirían a hacer más agradable la vida de sus pobladores, pues se logró, igualmente, una buena visibilidad de los terrenos circundantes erigiendo la villa sobre una suave ondulación del relieve, en un punto clave para el control de un bien tan escaso como es el agua, de cara a la explotación agrícola. Fue construida en una llanura poco resguardada de las corrientes de aire y de los rigores del frío invierno meseteño, mas, pese a no tener un emplazamiento acorde con la pauta de buscar un sitio abrigado en la estación invernal, lo cierto es que recibía muchas horas de insolación ${ }^{2}$, un factor especialmente propicio para sus habitantes. Además, posiblemente se tuvo en cuenta que estaba bien aireado en verano, circunstancia muy conveniente durante la época de estío en esta zona del interior peninsular, cuyo clima es continental y, por consiguiente, bastante extremado. En ese sentido, Columela (De r.r. I, 4,4) prescribía que, previamente a la instalación de cualquier villa, se estudiara la dirección y variabilidad de los vientos.

A la hora de escoger el lugar donde erigir ésta debió de ser determinante la proximidad de los arroyos antes mencionados, no sólo para proveer de agua la vivienda señorial y la hacienda (Varro, rust. I, 11,2), sino para atemperar el intenso calor veraniego, como aconsejaba Columela (De r.r. I, 5,4).

En este espacio físico idóneo se desarrolló un modelo de asentamiento característico del mundo romano, que dejó su impronta en el medio rural durante largo tiempo (en la región manchega siguen siendo típicas las quintas o quinterías, que funcionan como núcleo centralizador de grandes haciendas).

Para abordar el estudio de esta villa conviene tener en cuenta algunas observaciones previas, con el

2. Esa era una de las premisas recomendadas por Varrón (rust. I, 12,3) y otros tratadistas latinos en agronomía para la elección del lugar donde se pretendía construir una residencia rústica.

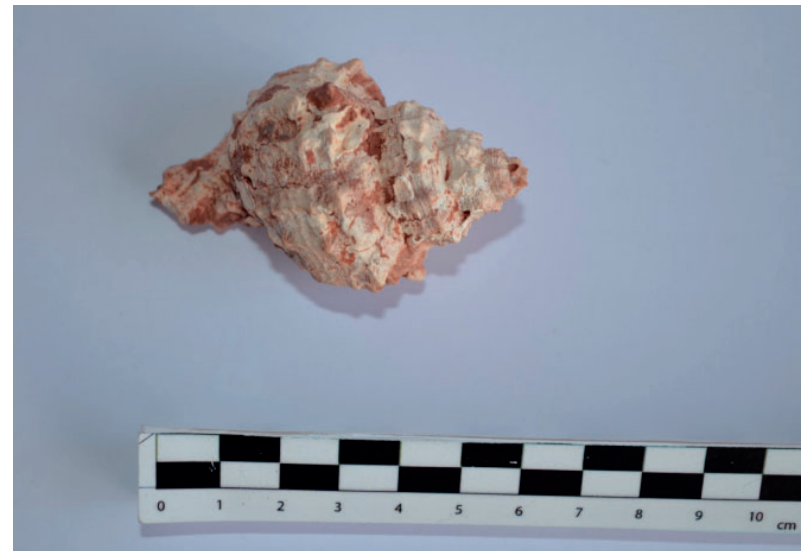

Figura 4: Gasterópodo. Foto: García Bueno.

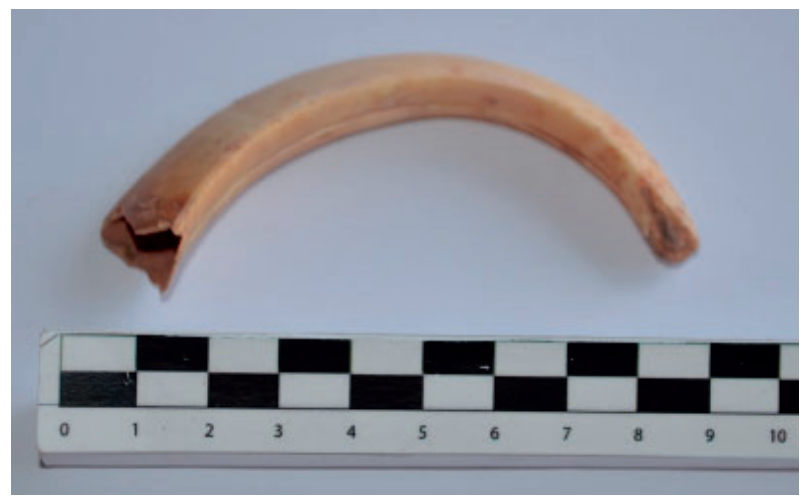

Figura 5: Colmillo de jabalí. Foto: García Bueno.

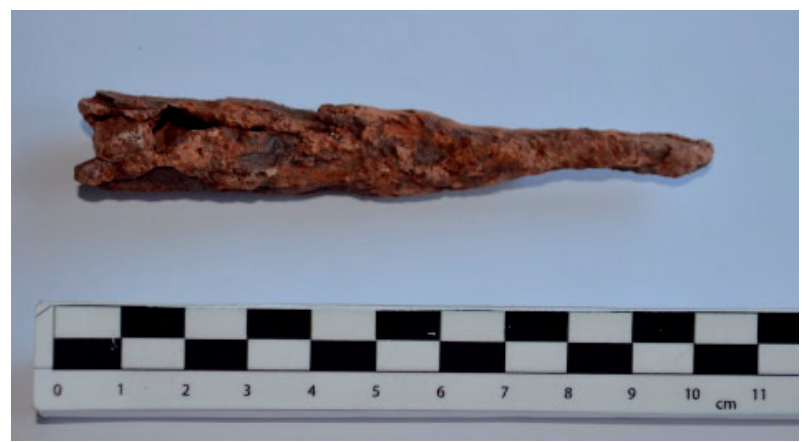

Figura 6: Regatón de hierro. Foto: García Bueno.

propósito de acercarnos, en la medida de lo posible, a la realidad cotidiana de quienes la habitaban.

Este tipo de establecimientos agropecuarios solía instalarse en pagi fecundos. Así, el aprovechamiento de las tierras que rodean la villa de Puente de la Olmilla ha continuado hasta los tiempos actuales (Fig. 3), basado fundamentalmente en el olivo y el cereal (trigo, cebada...). Viene al caso un texto de Apiano ( $I b$. 64) sobre la existencia de abundantes plantaciones de olivo en la Meseta meridional. Los agrónomos latinos (Cato, agr. I, 1,2 y Varro, rust. I, 12,1, entre otros) aconsejaron reiteradamente la adquisición de fincas fértiles con el fin de obtener la mayor rentabilidad posible en su explotación. Conforme a las orientaciones 


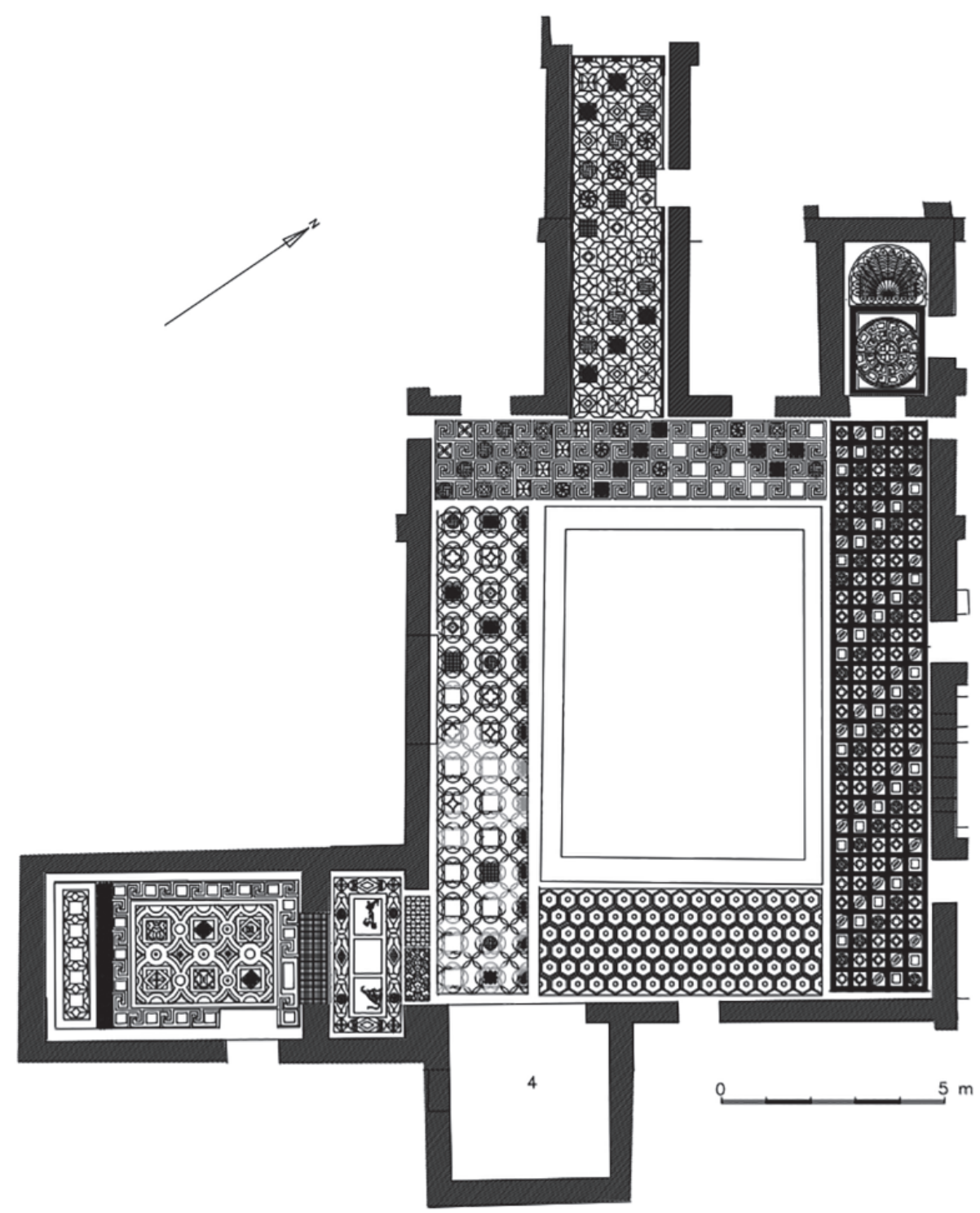

Figura 7: Restitución de la decoración musiva. Dib.: García Bueno.

de dichos tratadistas, este espacio geográfico tiene unas condiciones naturales favorables y reúne varios de los requisitos de habitabilidad indispensables al decir de los mismos (Cato, agr. V, 2; Colum., De r.r. I, 6,1; Varro, rust. III, 2,9), incluyendo la belleza del paisaje, para que el dominus pudiera gozar de la naturaleza, descansando en este remanso de paz, un lugar apacible y apartado, pero no completamente aislado, ya que mediante algún camino secundario se relacionaría con los principales ejes de comunicación. Además de disfrutar de la tranquilidad que le proporcionaría este retiro, inmerso en el profundo sosiego de estos campos, podría dedicarse a diversas ocupaciones (Carandini et alii, 1982, 67-89), entre otras, a una de las actividades lúdicas favoritas de los possessores: la caza (Lavin, 1963, 179-286; Gorges, 1979, 155-158; Chavarría, 2007, 82), tradición que ha llegado hasta nuestros días, pues es una magnífica zona cinegética.
En el registro arqueológico figuran restos óseos faunísticos que corroboran el consumo de animales provenientes del entorno (aparte de otros foráneos, p. ej., moluscos marinos, Fig. 4). Algunos, como son los de jabalí (Fig. 5), confirman la práctica de la caza, de la que probablemente también nos ofrece testimonio material un regatón de hierro hallado cerca del pórtico exterior (inmediatamente al Oeste del mismo), cuyas dimensiones son $10 \mathrm{~cm}$ de largo x $1,80 \mathrm{~cm}$ de ancho (Fig. 6). La pieza, hueca y apuntada, tiene un orificio en uno de sus extremos concebido para que un pequeño clavo facilite la unión al asta de madera.

\section{DESCRIPCIÓN DE LA VILLA}

En el proceso de excavación de Puente de la Olmilla se ha descubierto un patio central, el peristilo que lo circunda, más de una treintena de recintos de distinto 


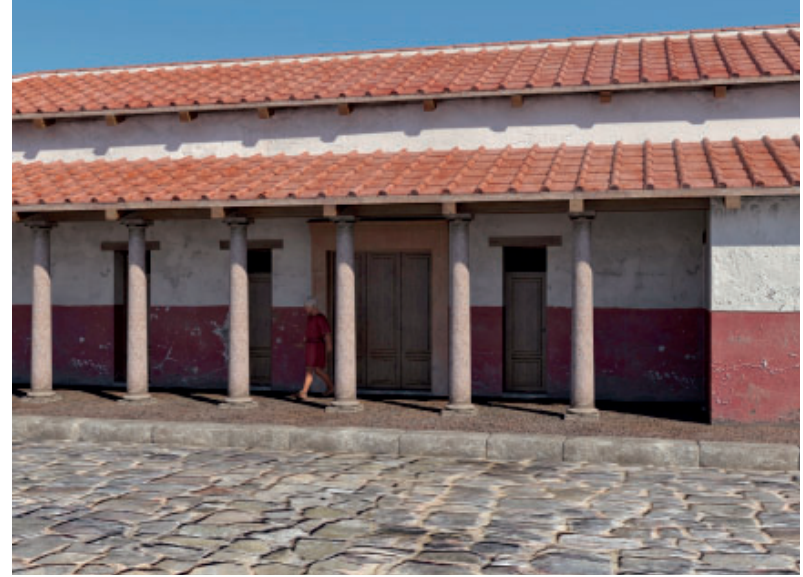

Figura 8: Reconstrucción hipotética virtual de la fachada de la villa, según García Bueno. Imagen cedida por el MP de Ciudad Real.

rango, un posible pórtico exterior y el pasillo de entrada, permitiéndonos conocer bien el sistema de circulación de la villa. Algunos de esos ambientes están ricamente decorados con paredes revestidas de estuco pintado, de amplia variedad cromática, y pavimentados con mosaicos policromos de gran diversidad ornamental, en diferentes grados de conservación (Fig. 7), que conjuntamente crearían bellos efectos de luz y color.

Es significativo el dato relativo a la extensión del sector donde se ha intervenido hasta ahora. Si juzgamos por las huellas arqueológicas perceptibles a simple vista, calculamos que el edificio superaba con holgura los $1.225 \mathrm{~m}^{2}$ de superficie útil. En efecto, algunas alineaciones de estructuras que apenas afloran al exterior y la dispersión superficial de la cerámica, del material latericio y de cubrición en un perímetro de unos $300 \mathrm{~m}$ en derredor de las ruinas exhumadas, apuntan a una ocupación mucho más amplia. Además, al observar los muros exteriores de la zona delimitada podemos comprobar que la edificación se prolonga por los cuatro costados, con la salvedad del frente noroccidental, donde apenas localizamos (al Norte) una estructura más allá de la galería porticada ${ }^{3}$ que interpretamos como fachada principal de la residencia $\left(n{ }^{\circ}\right.$ 13, Fig. 8$)^{4}$.

Puente de la Olmilla corresponde, por tanto, al tipo de villa de peristilo, ampliamente difundido en la

3. La planta de este edificio solariego, reformada en el transcurso de su ocupación, es el resultado de diversos reajustes y ampliaciones llevados a cabo a lo largo de los años. En la última fase constructiva, se rehízo la sección del pórtico exterior y se añadieron algunos muros de cierre.

4. Queremos dejar patente nuestro más sincero agradecimiento a la Consejería de Educación, Cultura y Deporte de la JCCM, por permitirnos reproducir una serie de infografías realizadas para el Museo Provincial de Ciudad Real a partir de algunos de nuestros dibujos e investigaciones del yacimiento de Puente de la Olmilla.
Península Ibérica (Gorges, 1979, 121, fig. 19, D, 125 126; Fernández Castro, 1982, 70-77, 171, figs. 84G, 90, n. ${ }^{\circ} 30,96 \mathrm{~B}$; Chavarría, 2007, 208-209, n. ${ }^{\circ} 36$, fig. $62)$, pero también está caracterizada por el referido pórtico exterior (Figs. 8-10). Este esquema arquitectónico, en el que se combinan ambos elementos, no es muy usual en Hispania (cfr. los ensayos de síntesis de Gorges, 1979, láms. XXIV-LXX y Chavarría, 2007, 167-297, con sus respectivos catálogos). En contraposición a lo expresado por esta última investigadora (Chavarría, 2007, 108) respecto a que algunas de estas residencias responden «a una concepción de edificio muy compacto cerrado al exterior (prácticamente todas las villae de peristilo)», la de Albaladejo rompe dicho esquema, abriéndose al medio externo a través de una loggia. Como tónica general, un marcado criterio de simetría y una cierta tendencia a la regularidad caracteriza a esta villa, en la que prevalece su unidad interna. En síntesis, las cuatro alas ocupadas por una serie de estancias dispuestas en torno a un núcleo probablemente ajardinado, que les aporta luminosidad y desde el que se accede a ellas mediante las galerías de circulación del peristilo, forman un conjunto de planta agrupado a su alrededor de manera bastante coherente y bien proporcionada, sin llegar a caer en una monótona uniformidad, pues quien proyectó esta residencia le incorporó algunos elementos arquitectónicos no demasiado comunes, tales como el citado corredor por el que se realizaba el tránsito desde el porche (n. ${ }^{\circ} 11$ y 13, Fig. 9) y se enfilaba hacia el peristilo, constituyendo dos ejes perpendiculares en función de los que se distribuían varias dependencias, al Norte y Oeste. Desde el punto de vista planimétrico, esa galería (n. ${ }^{\circ}$ 13) de la que está dotada la villa es una de sus particularidades más reseñables. Aunque ésta sería la entrada general durante la etapa tardía, parece ser que en un primer momento no fue la única: el edificio primitivo pudo contar con otros dos accesos, tal vez secundarios, que lo pondrían en contacto con el exterior, al Este por la habitación $\mathrm{n} .^{\circ} 25 \mathrm{y}$ al Oeste por la n..$^{\circ} 7$ (si bien este último pudo ser en un comienzo el punto de ingreso principal). A consecuencia de las ampliaciones paulatinamente realizadas, después ya no se podría pasar directamente desde fuera al interior a través de esas dos grandes puertas situadas en lados opuestos de la casa, respondiendo ese hecho a los nuevos planes constructivos programados, que se adaptarían a lo que requerían unas circunstancias, con toda probabilidad, diferentes a las iniciales.

Como indicación general podemos decir que la planimetría que presentamos es bastante expresiva, aun siendo parcial, pues sólo se conoce completo el cuerpo central del edificio. Seguidamente realizaremos una descripción más pormenorizada de su estructura arquitectónica e intentaremos identificar el papel que desempeñaron las unidades constructivas descubiertas. Un acercamiento interpretativo define a Puente de la Olmilla como una amplia residencia señorial organizada en derredor de un patio porticado, en torno 


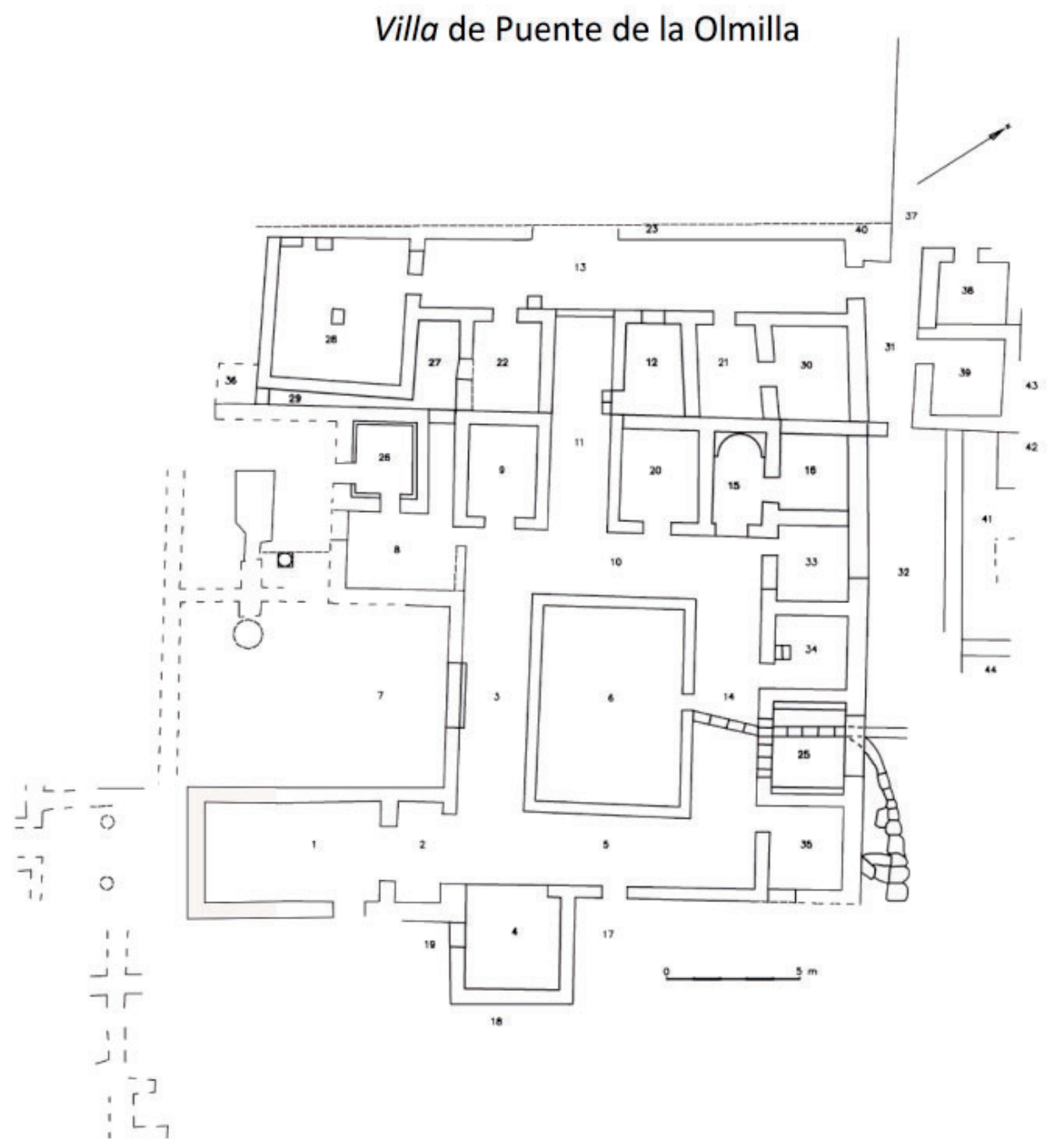

Figura 9: Planta general de la villa, según García Bueno.

al que gira la mayoría de los ambientes. Este conjunto formado por una célula rectangular y su peristilo no se articula como una unidad de espacio cerrado, pues a él se accede a través del corredor de entrada (n. $\left.{ }^{\circ} 11\right)$, desde la galería con columnas que recorre la fachada frontal (n. $\left.{ }^{\circ} 13\right)$, abierta al Noroeste, dando así plasmación arquitectónica al propósito de tener una apertura directa al exterior, como ya habíamos anticipado. En este sector noroccidental de la casa, a ambos lados de dicho pasillo (n. $\left.{ }^{\circ} 11\right)$, hasta llegar al peristilo, se distribuyen en doble hilera dos grupos de dependencias de pequeñas dimensiones (salvo la n. ${ }^{\circ} 28$ ), que constituyen un bloque constructivo cuya profundidad tiene la longitud de las fauces. Probablemente algunas de ellas estaban destinadas a actividades productivas y otras eran cubicula.

En el flanco situado al Oeste del pasillo n. ${ }^{\circ} 11$ hay diversos ámbitos pertenecientes a épocas distintas, como se desprende de su falta de homogeneidad: algunos muros no tienen zanja de cimentación (se asientan directamente en el sustrato rocoso del terreno), a diferencia de los restantes, y otros fueron rotos o añadidos, además, varios paramentos estaban compuestos por mampostería alternada con tejas, un tipo de fábrica que los distingue de la mayoría de las estructuras, excepto las del Noreste, de idéntica factura. Cuando se construyeron los departamentos 26 y 28 se alteró parcialmente el diseño primitivo de esta zona, resultando de ese replanteamiento arquitectónico dos espacios angostos, a modo de «pasadizos» (n. ${ }^{\text {o }} 24$ y 29), que después fueron tapiados, perdiendo así toda función práctica, al igual que le sucedió a la habitación 27 . También en una fase constructiva posterior a la fundacional se levantó un muro de adobe al Noroeste del deambulatorio n. ${ }^{\circ} 3$, delimitando una puerta por la que se realizaba el tránsito desde el mismo a la habitación 8 (inicialmente mucho mayor), a su vez comunicada con los referidos ambientes 24 y 26, a la par que este último (el n. $\left.{ }^{\circ} 26\right)$ fue edificado en el área noroccidental de dicho recinto $\mathrm{n}^{\circ}{ }^{\circ} 8$, subdividiéndolo de esa manera, según apuntan todos los indicios. Se modificó así la organización interna de esta parte de la villa, como consecuencia de una remodelación puntual dentro del plan general de la vivienda. La más amplia de estas estancias es la n. ${ }^{\circ} 28$, de planta cuadrada. Adosados a su muro septentrional, aparentemente colocados allí, hay 
dos fuertes lastras o sillares de arenisca que podrían haber servido de punto de apoyo para sendas columnas o bien para sostener unos tablones -e inclusive instalar una tarima de madera-sobre los que depositar cereales u otros víveres, con el fin de aislarlos de la humedad del suelo. Cerca del más oriental de esos basamentos aparece un plato de hierro, asociado a una bolsada de carbones y cenizas. Consignamos el hallazgo de un as de Marco Aurelio o Cómodo, varios fragmentos de pequeños recipientes de vidrio, abundante cerámica común, restos óseos faunísticos, un contenedor de hierro en estado fragmentario, varios fragmentos de este mismo metal pertenecientes a objetos de filiación indeterminada, clavos, un fragmento de escoria mineral, una placa broncínea, un fragmento de roca volcánica (tal vez de un molino rotatorio) y otro de mármol. También se documenta gran cantidad de fragmentos de un piso de opus caementicium destruido. Podría haber tenido un uso de almacenaje u otros fines utilitarios, como parece inferirse del repertorio de materiales arqueológicos y los elementos constructivos de soporte repartidos por su interior (vid. infra). Acaso para facilitar las tareas a las que esta espaciosa cámara estaba destinada, se la hizo directamente accesible desde el exterior, haciendo innecesario penetrar en la casa.

Otro conjunto de seis compartimentos adyacentes formado por dos filas de tres se dispone al Este del corredor principal (n. $\left.{ }^{\circ} 11\right)$. En ellos se puede detectar diversas refacciones, atribuibles a etapas distintas. A dos de los más septentrionales (el 12 y el 21) en un principio se entraba por el Noroeste, directamente desde el pórtico (n. ${ }^{\circ} 13$ ), en tanto que al $n .^{\circ} 30$ sólo se podía llegar a través del cuarto colindante, el $\mathrm{n}^{\circ}{ }^{\circ}$ 21, ubicado en el centro de esta alineación. El tipo de materiales arqueológicos (herramientas tales como un hacha, utensilios como un cuchillo de hierro, cerámica común y de almacenamiento, piedras de molino, restos óseos faunísticos, etc.) proporcionados por la excavación de los departamentos 12, 21 y 30, además de la posición de éstos, con acceso inmediato desde el pórtico (al menos inicialmente, en el caso del n. ${ }^{\circ}$ 12), y los suelos de cemento o tierra batida, parecen indicar que se trata de una zona de servicio.

La segunda alineación se compone de otros tres aposentos, entre los que destaca el de en medio (n. $\left.{ }^{\circ} 15\right)$ debido a su traza arquitectónica -tiene un remate absidial en el lado norte-, asimismo, a estar sobreelevado y tapizado con un armonioso mosaico, adaptado a la cabecera. La exedra semicircular parece haber sido añadida a una planta originariamente rectangular, pues se aprecia que ha sido adosada a la cara interna del muro de cierre septentrional, no construida al mismo tiempo que dicha estructura. El testero no se trasluce al exterior, ya que el muro en el que está englobado no dibuja esa misma línea curva, por ende, la habitación no fue ampliada con el ábside. La inclusión de ese elemento morfológico-decorativo acentúa la importancia de esta cámara, que recibió en esa segunda fase un acondicionamiento de calidad. A tenor de las características ornamentales y formales de que está dotada, era una de las más privilegiadas de la casa, pero, con sus $11 \mathrm{~m}^{2}$, la consideramos algo pequeña para poder asumir la representación pública, como oecus. Por la misma razón, tampoco nos convence totalmente la interpretación como triclinium ofrecida por M.C. Fernández Castro $(1982,108,206)$. Podríamos aventurar la teoría de que primitivamente fuera un cubiculum (o un ámbito de cualquier otra índole, pero, desde luego, de menores pretensiones decorativas), transformado después en un lararium tipo sacrarium, o desde el principio podría haber sido una capilla doméstica, con algunos añadidos posteriores para dignificarlo y hacerlo sobresalir entre los habitáculos de su entorno, mediante ciertos componentes ennoblecedores (¿con el fin de subrayar su valiosa significación, como espacio reservado al culto?, esto último en el caso de haberse mantenido ese supuesto uso, es decir, si hubo una continuidad, perdurando la misma función religiosa). Por contra, todo apunta a la referida variación de destino, sea éste el que fuere, o bien, si no tuvo inicialmente otro diferente (cubiculum ...), podría deberse al deseo de priorizar por algún motivo este recinto en un segundo periodo constructivo, en el que habría adquirido nuevos elementos de realce: el pavimento musivo, una decoración pictórica policroma (vid. infra) y la exedra. Eso explicaría que ésta fuera incorporada a posteriori, cuando se cubrió la habitación con un solado en opus tessellatum. La intención subyacente de singularizarla, materializada también mediante su cota superior y su escalón de acceso, para salvar un desnivel de $10 \mathrm{~cm}$, se constata, p. ej., en la capilla de la villa de Vilauba, en Camós, Gerona (Pérez Ruiz, 2010, II, 184-193; 2012, 244; para más información sobre los lararios, Pérez Ruiz, 2014, con una completa bibliografía específica). Cabe proponer que fuera un espacio para acoger las ceremonias rituales de culto doméstico, coexistiendo, quizás, con otras actividades perfectamente compatibles aunque heterogéneas (realizar actos culturales, reunirse con invitados selectos, amigos..., siendo dedicado a conversar, leer, celebrar ceremonias familiares, o/y como gabinete de trabajo del dominus, donde éste podría retirarse también para atender sus asuntos, gestionar sus negocios...), por lo que pudo haber una multiplicidad de las mismas e inclusive éstas pudieron ir cambiando a lo largo de los años. Tampoco podemos descartar que fuera una segunda sala de prestigio, sin otras connotaciones. Los exiguos materiales arqueológicos no contribuyen a esclarecer la finalidad de este compartimento. Consisten en alguna cerámica común, varios clavos de hierro y un gancho de este mismo metal, fragmentos metálicos indeterminados, restos óseos faunísticos y un fragmento de vidrio.

Está intercomunicada con una pieza posiblemente adicional (n. $\left.{ }^{\circ} 16\right)$. Esa supuesta anexión respondería, quizás, a una función subsidiaria de este último reducto con respecto al espacio aledaño, pues únicamente a través de éste $\left(n .^{\circ} 15\right)$ se dará entrada al $n .^{\circ} 16$, una vez fue inhabilitada su puerta original, mediante la que 
anteriormente estaba conectada con la contigua unidad habitacional n. ${ }^{\circ} 33$. Así pues, aparte de la renovación de la $n .^{\circ} 15$, constatamos la realización de ciertas modificaciones estructurales en toda esta sección, como el cierre de tres vanos, dos de ellos tapiados con mampuestos (ambientes n. ${ }^{\circ} 16$ y 20 ) y otro con adobes (en el n. ${ }^{\circ} 12$, impracticable desde el pórtico exterior a partir de entonces), o la abertura de otros, uno de ellos a modo de punto de iluminación y no sólo de comunicación de los ambientes 11 y 12, u otro que permitió pasar desde la habitación 15 a la 16 en un periodo ya muy tardío. Esos reajustes afectaron incluso al pavimento de la primera estancia (n. $\left.{ }^{\circ} 15\right)$ y todos ellos corresponden a una etapa constructiva ulterior, en una fecha difícil de precisar más con los datos por ahora disponibles. Según esta perspectiva, y como hipótesis de trabajo, podría haber surgido la necesidad de ampliar la habitación 15, cuyas proporciones tal vez resultaban demasiado reducidas para la función que se le otorgó a posteriori, por lo que se le habría incorporado ese otro espacio limítrofe (el n. $\left.{ }^{\circ} 16\right)$. Éste pudo ser dedicado a un servicio accesorio del colindante, o quizás se hizo simplemente con la intención de crear una comunicación directa entre los recintos 15 y 16, por la razón que fuere. Una de las alternativas posibles es que en un momento ocupacional avanzado, el primero de ellos dejara de cumplir la supuesta función de capilla doméstica, pues generalmente los lararia no sirven de antesala (aunque pudo mantenerse un uso religioso del ábside), eso podría haber provocado cambios puntuales del esquema previo, y a partir de entonces podría haberse convertido en un cubiculum compuesto de alcoba y vestíbulo, como el conjunto de la villa de Els Munts (Pérez Ruiz, 2014, catálogo en $\mathrm{CD}$ ), recuperando su posible identidad primigenia (en el caso de haber sido primero un cubiculum y no un sacrarium o un aposento noble desde su origen), pero ahora asociado al n. $^{\circ} 16$.

Al Este del brazo oriental del peristilo (n. $\left.{ }^{\circ} 14\right)$, desde el que son accesibles, se dispone una serie de cuatro habitáculos yuxtapuestos (n. ${ }^{\circ} 33,34,25$ y 35), bastante homogéneos en cuanto a su tamaño y morfología (son de planta cuadrada). Entre ellos destaca el n. ${ }^{\circ}$ 25, especialmente por tener una gran puerta, tal vez en un principio de exterior, por lo que posiblemente fue otro punto de ingreso a la villa por el flanco oriental, dadas sus características formales, pero en un momento dado fue parcialmente sellada con ladrillos, con el fin de estrecharla. Seguramente se debió a que se adosaron por el Este diversas dependencias y pasillos distribuidores de nuevas estructuras arquitectónicas, de manera que esa puerta se habría convertido en la entrada a una simple habitación más, motivo por el que se la redujo considerablemente. También la habitación n. ${ }^{\circ} 33$, en su mismo eje, se comunicaba por el Este con dicha área, hasta que después fue cegado el vano que permitía un acceso directo, impidiéndose de esa manera el tránsito desde esta sección de la vivienda al nuevo módulo lateral añadido a la misma, algo alejado del peristilo y sólo en parte excavado. Por lo tanto, existen varios planos de edificación. En cuanto a la definición funcional de esta área, la presencia de dos hoces, un molino rotatorio, abundante cerámica común, fragmentos metálicos y vítreos, material óseo de fauna diversa (un asta de cérvido...), valvas de moluscos (ostra...), etc., sugiere que pudiera haber sido dedicada al almacenamiento de utillaje agrícola y productos alimenticios, además de a su procesamiento, por lo que se trataría de instalaciones subalternas, con suelos de tierra batida. Son dignos de mención varios fragmentos de terra sigillata, en particular, una base de TSH con la marca de alfarero EX OFP o quizás EX OF PT, cuya última letra está parcialmente perdida. Como es habitual, el sello es rectangular, de extremos redondeados, estampado en el fondo del recipiente después del secado de la arcilla (postcocción). El barniz de esta pieza, lisa, probablemente una 27, es de buena calidad. Muy posiblemente fue producida en un alfar de Andújar. Se encontró al limpiar uno de los muros de la habitación n. ${ }^{\circ} 35$.

La planta, en conjunto, no parece haber sido demasiado alterada. Básicamente, en resumen, las reformas practicadas consistieron en varios huecos ocluidos, otros abiertos, la compartimentación espacial de algunas zonas, la reestructuración del porche exterior y la construcción de nuevas habitaciones, como es el caso de la primera crujía noroccidental (pareja a la prolongación de los muros del pasillo n. ${ }^{\circ}$ 11) u otra ala en el lado nororiental y oriental de este complejo doméstico, que mediante dos largos corredores ensamblados (n. ${ }^{\circ} 31$ y 32) articula la dispersión de, al menos, otros siete departamentos al Noreste-Este del edificio primitivo (los n. ${ }^{\circ} 37,38,39,41,42,43$ y 44), sin más transformaciones apreciables del plano original de la casa. No obstante, es posible que éste experimentara alguna otra ampliación en un momento más tardío.

En los sectores occidental y meridional se integran otra serie de entidades habitacionales: las n. ${ }^{\circ} 1,2,7$, $36,45,46, i 47$ ? y 48 . Las dos primeras, soladas con magníficos pisos en opus tessellatum, están comunicadas entre sí. Un pequeño lienzo musivo decorado con un damero, en el umbral de la puerta intermedia, separa ambos mosaicos (sobre el virtual efecto señalizador de la ornamentación musiva, cfr. Vaquerizo et alii, 1994, 112). La n. ${ }^{\circ} 2$, de dimensiones más reducidas que la colindante, con la que está coordinada, se abre en el lateral suroeste del peristilo. Tras sobrepasarla, se llega a la mayor de ellas (la n. ${ }^{\circ} 1$ ), que tiene dos vanos. Al Oeste de la misma, dos columnas preceden y marcan el acceso a otro ámbito (habitación 48), en el límite de la excavación. El conjunto unitario formado por las habitaciones 1-2, a modo de cámara y antecámara, debió de ser uno de los espacios preeminentes de la residencia, quizás el triclinium. Su programa ornamental, su configuración arquitectónica, su tamaño y la amplitud de sus respectivas puertas parecen conferirles un valor de representación. El diseño figurativo elegido para pavimentar la habitación 
2 subraya, sin duda, la importancia del recinto que decora, definiéndolo como uno de los de mayor alcurnia de la villa. Atendiendo a que el thyasos se reproduce asiduamente en los programas pavimentales de los triclinia, dada la sagrada conexión entre Dionisos y el banquete, esta clave podría ayudarnos a averiguar su destino. La iconografía musiva dionisíaca sería muy apropiada para una sala donde se llevara a cabo la práctica social del convivium, aunque el imaginario dionisíaco se despliega ocasionalmente en unidades domésticas de otra índole (p.ej., en la villa de La Malena se adornó el oecus con un mosaico báquico, Royo, 2001, 46-57), por ello no podemos establecer una identificación automática, al no existir una vinculación excluyente entre ciertas temáticas musivas y los ambientes donde se insertan. Por lo que atañe a los materiales arqueológicos recuperados, son muy escasos (salvo los de cubrición) y no arrojan ninguna luz sobre su posible funcionalidad: se trata de cerámica común bajoimperial, una basa de columna, clavos de hierro, un as de época augustea, una maiorina de Teodosio I y un centenionalis de Honorio.

A la izquierda del patio se levanta una vasta habitación centrada respecto al mismo, la n. ${ }^{\circ} 7$. Considerando el gran tamaño de su umbral, probablemente en un principio serviría de vestibulum, como una de las entradas secundarias de la residencia o incluso, en esa etapa inicial, pudo ser la puerta principal de acceso desde el exterior -concretamente por el Oeste-. Contemplamos la posibilidad de que su destino cambiara después, al ampliarse la vivienda, cuando tal vez se convirtió en una de las espaciosas estancias dedicadas a actividades sociales, pues destaca tanto por su localización, frente al lado mayor del patio, como por las grandes dimensiones de la sala (que superan a las de todas las demás), pero no por su decoración, al carecer de la suntuosidad que le proporcionaría un tapiz musivo, ya que está pavimentada con un modesto opus caementicium... Si bien el estado actual de las investigaciones dificulta determinar su identidad, no sería el único caso en el que no se habría mantenido el uso primigenio de una habitación, dado que en varias de ellas parece haberse producido una reconversión funcional, como ya expusimos. Se nos plantean, por tanto, algunos interrogantes de interpretación no del todo resueltos satisfactoriamente. Comúnmente, en la arquitectura privada imperial las habitaciones de recepción, comedor y descanso se organizan en derredor del patio porticado (Fernández Castro, 1978, 316), siendo el centro de atención decorativa de la misma.

En esta área occidental se encuentran las unidades constructivas de mayor tamaño de las excavadas hasta ahora (n. $\left.{ }^{\circ} 1,2,7,8,28,45,46 \ldots\right)$, a las que se une la n. ${ }^{\circ}$, al Sureste, muy cercana a las dos primeras enumeradas. La última mencionada (n. $\left.{ }^{\circ} 4\right)$ está prácticamente en posición axial respecto a la entrada a la villa, gozando de una situación especialmente privilegiada dentro de la pars urbana. La villa de Puente de la Olmilla se articula, por tanto, sobre un eje de simetría NO-SE que recorre el pasillo de acceso al interior de la vivienda, hacia el patio porticado, presidido al fondo por esta sala cuadrangular, la n. ${ }^{\circ} 4$, probablemente la de mayor rango. Tiene una superficie útil ligeramente inferior a los $21 \mathrm{~m}^{2}$. Su ubicación preferente dentro del conjunto arquitectónico, su ancha puerta, el revestimiento de sus paredes con paneles pictóricos de elegante colorido y de su suelo con un bello mosaico figurativo, a lo que se agregó un elemento específicamente ennoblecedor al ponerla en un plano más alto, con objeto de hacer patente su primacía funcional, todo ello, en suma, la hace susceptible de ser interpretada como una de las salas de aparato, posiblemente el oecus. Esta opción parece muy verosímil, por el hecho de estar realzada, como suele suceder en las habitaciones áulicas, y tener un solo punto de ingreso, cuya anchura supera a la de los restantes, como ocurre en muchos ámbitos de representación. Asimismo, el mosaico seleccionado, con un tema mitológico (los Cuatro Vientos), es idóneo para transmitir la imagen especialmente distinguida que requería un salón de recepciones. Recapitulando, algunos de estos espacios habitacionales tenían un carácter señorial. La funcionalidad de este tipo de habitaciones está marcada tanto por su diseño arquitectónico como por su posición dentro de la planta general. Además, sus pinturas parietales y, en algunos casos, los suelos cubiertos con ricas alfombras musivas contribuyeron a darles una notable importancia ornamental.

Dentro de la dicotomía de las unidades domésticas romanas, con su doble dimensión pública y privada, en esta villa las funciones públicas de recepción están, según parece, en cierta medida segregadas de las más privadas, como intentando diferenciar los lugares a los que tenía acceso la comunidad de los reservados a lo cotidiano (destinados a habitación de la familia propietaria). Los primeros $\left(n .^{\circ} 1,2,4 \ldots\right)$ son accesibles desde los principales circuitos internos de tránsito y están dotados de una serie de elementos de prestigio, entre los que consignamos los pavimentos musivos más selectos, una mayor amplitud tanto de esos espacios del ángulo meridional de la villa como de los vanos de entrada a ellos, etc.

Aunque los límites de esta residencia quedan fuera del solar excavado al no haber salido hasta ahora a la luz todos los muros perimetrales, como ya hemos comentado, en sus inmediaciones la labor de los arados ha hecho aflorar a superficie otras posibles alineaciones de muros y el acostumbrado material de derrumbe, vestigios de otras construcciones (contiguas o independientes, Fig. 10), que en algunos casos podrían tener un carácter subsidiario, por ser inherentes a los establecimientos rurales como éste, en los que, además de estancias pertenecientes a las mencionadas esferas representativa y privada, solía haber otras de servicio, específicas de la actividad agrícola desarrollada en ellos, e igualmente las que albergaban a los trabajadores de la finca. 


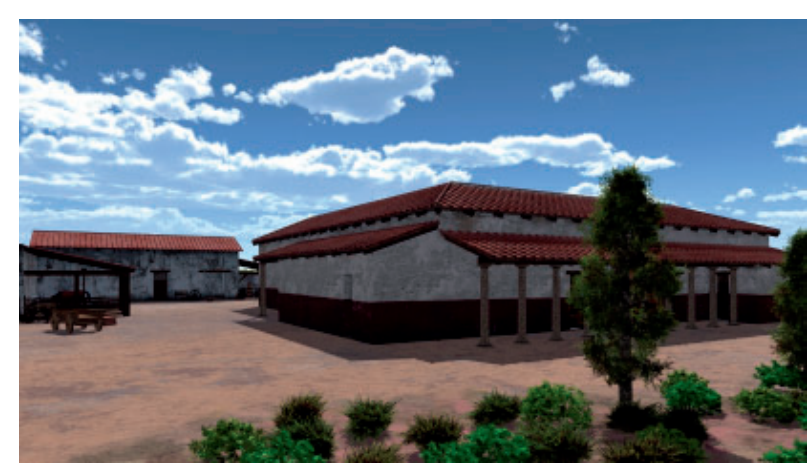

Figura 10: Reconstrucción virtual ideal de la villa. Al fondo, posibles estructuras utilitarias. Imagen cedida por el MP de Ciudad Real.

Por otro lado, pese a que no hemos recuperado ningún ladrillo-dovela y carecemos de cualquier otra evidencia material de la existencia en el conjunto exhumado de alguna estancia con cubierta abovedada (típica de los complejos termales, mas no sólo de éstos), como es lógico en una villa de estas características, la de Puente de la Olmilla estaría equipada con un balneum privado, diferenciado o no del ámbito doméstico propiamente dicho, tal vez al Sureste del mismo (sobre este particular, cfr. García Bueno, 2011, 449-472).

\section{TÉCNICA Y MATERIALES EDILICIOS}

En la fábrica de las unidades constructivas se emplearon piedras locales (fundamentalmente arenisca), sin trabajar o toscamente desbastadas, de formas y dimensiones variadas, predominando las de tamaño mediano, bien trabadas con mortero de argamasa y colocadas en hiladas más o menos regulares. Son estructuras muy consistentes, con recias cimentaciones sobre las que, según parece deducirse de ciertas evidencias arqueológicas, se alzaban paredes de adobe (así, p. ej., se acredita en las habitaciones n. 8 y 19) y, probablemente, aunque no se hayan conservado, de tapial. De la mayor parte de los muros tan sólo se han preservado las fundaciones. Las superficies parietales estaban revestidas con un enlucido de cal y frecuentemente decoradas con pinturas de rico colorido.

La anchura de esos muros construidos en mampostería no es totalmente uniforme, pero suelen medir $0,70 \mathrm{~m}$ y hay algunos tabiques de adobe de $0,40 \mathrm{~m}$ de ancho (habitaciones n. ${ }^{\circ} 8$ y 33 ).

Así pues, en lo que concierne a la técnica edilicia, el muro de mampostería se alternaría con ladrillos (utilizados para regularizar las hiladas de piedra del zócalo), al menos en algunos casos, y con adobes, lo que no debía de restar solidez al inmueble, mayoritariamente de muy buena calidad constructiva (en algunas otras villae se ha constatado el uso del ladrillo como material complementario de machones y esquinas, p. ej., en Las Mezquitillas, cfr. Santos, 1955, 47-48).
La piedra no sólo se aplicó en Puente de la Olmilla a los cerramientos, sino también a algunos umbrales y elementos de sustentación, como las columnas (Figs. 11-13). En efecto, han aparecido algunas basas, fustes $^{5}$ y escasos fragmentos de capitel, entre éstos es de reseñar uno de orden dórico y otro con molduración corintia o tal vez podríamos decir que es de estilo «corintizante», cuya ejecución es bastante tosca, quizás labrado por canteros locales. Podría tratarse de una posible variante regional, que intenta aproximarse al modelo clásico (sería una reinterpretación del mismo). Es de piedra arenisca, fácil de esculpir al ser blanda. De forma aproximadamente troncocónica, en su base mide $23 \mathrm{~cm}$ de ancho. Se conserva la parte correspondiente a las dos primeras coronas de hojas de acanto, que están envolviendo el kalathos. Muestra una decoración vegetal de ocho hojas de acanto sumamente estilizadas, apreciándose el intento de marcar unas nervaduras mediante líneas onduladas. Cabe deducir de la escueta descripción contenida en el Diario de excavación del año 1980 (donde se reproduce de manera esquemática en uno de los dibujos de R. Montanya y R. Puig) que es un trabajo de carácter muy local y bastante tardío, en definitiva, una pieza de arte provincial.

Del costado occidental del peristilo (n. ${ }^{\circ} 3$ ) procede un fragmento de columna que mide $60 \mathrm{~cm}$ de alto. Se trata de una media columna de arenisca, que en origen iría parcialmente adosada a la pared, como denota el tosco desbastado posterior. En esa parte, que no sería visible en su momento de uso, tiene una especie de pestaña que la recorre de arriba abajo e iría incrustada en el paramento (corresponde al tipo de columna empotrada, a modo de pilastra). La basa de esta columna tiene una altura de $14 \mathrm{~cm}$. Labrada en un solo bloque pétreo junto con el fuste, está compuesta por un plinto cuadrado (de $9 \mathrm{~cm}$ de alto y cortado por la mitad), el toro, que mide $7,5 \mathrm{~cm}$ de alto, el himoscapo, de $7 \mathrm{~cm}$, y parte del fuste (de $36,5 \mathrm{~cm}$ de altura), que es liso (Fig. 11). También es de destacar una basa de columna recuperada en la habitación $n .^{\circ} 35$, con un plinto de $39 \mathrm{~cm}$ de lado y una altura total de $18,5 \mathrm{~cm}$ (Fig. 12). En el muro meridional de esta dependencia hay una segunda puerta, cegada con una basa de columna adosada a la pared, cuyo plinto cuadrado mide $30 \mathrm{~cm}$ de lado por $10 \mathrm{~cm}$ de alto, el toro tiene $4,5 \mathrm{~cm}$ de alto y el himoscapo, también $4,5 \mathrm{~cm}$ de alto por $23,5 \mathrm{~cm}$ de diámetro. Su presencia, al haber sido reutilizada,

\footnotetext{
5. Procedentes de la villa de Puente de la Olmilla hemos localizado elementos arquitectónicos tales como basas y fustes de columnas en algunas viviendas de Albaladejo, todos ellos labrados en piedra local (arenisca), idénticos a los descubiertos al excavar este yacimiento. A su vez, M. R. Puig Ochoa y R. Montanya Maluquer depositaron algunos otros en un almacén del Ayuntamiento de Albaladejo, cuyo paradero actual se está investigando. En el proceso de excavación fueron hallados varios fragmentos de las columnas del pórtico de fachada, que estarían regularmente repartidas a lo largo de ese espacio rectangular.
} 

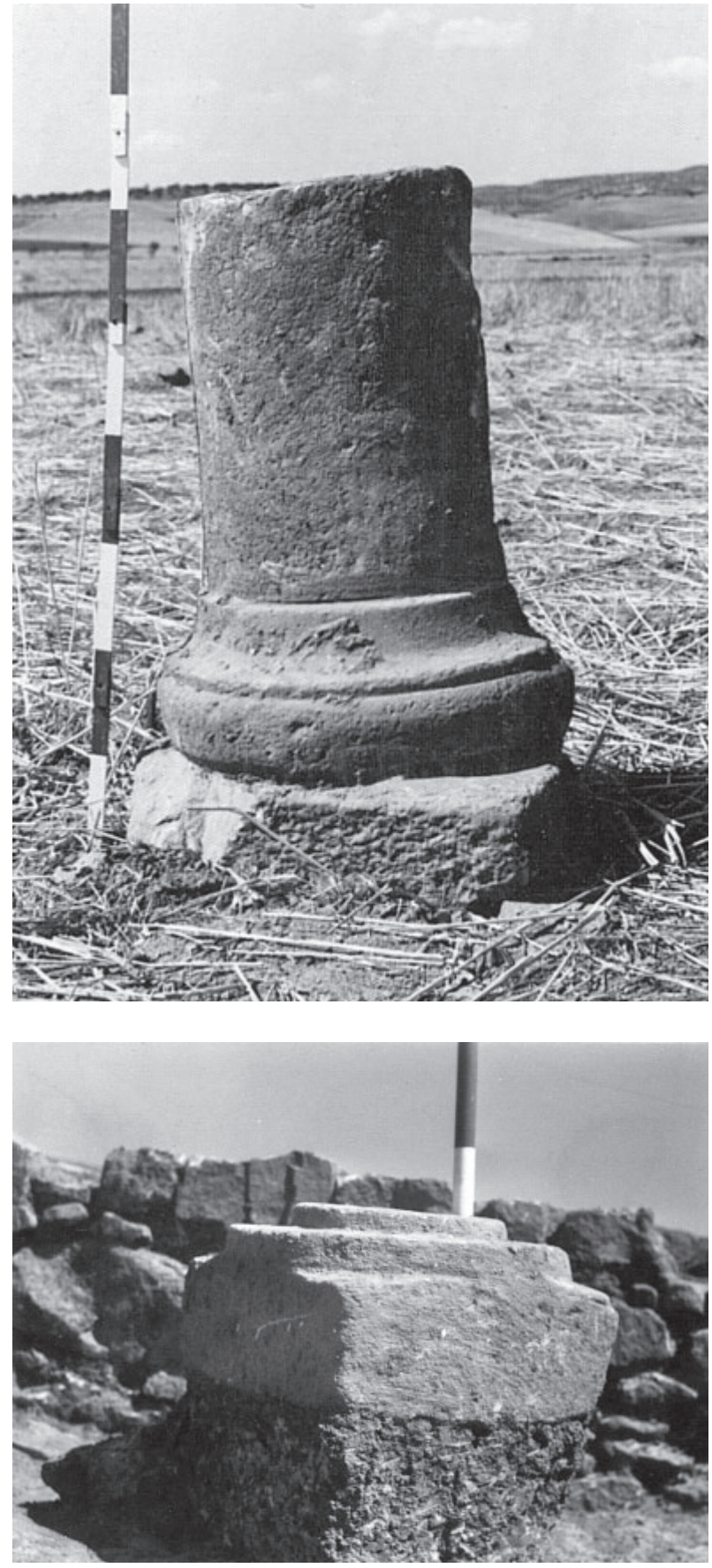

Figuras 11-12: Fragmento de columna monolítica del pasillo n. 3 y basa de columna de la habitación n. $^{\circ} 35$. Foto: Puig y Montanya (AGA).

desvela las sucesivas fases edilicias experimentadas por esta zona.

Asimismo, a través de un vano abierto en el muro septentrional de la habitación 22 se ingresaba a ella directamente desde la galería de fachada (n. $\left.{ }^{\circ} 13\right)$. En su exterior, dicha entrada estaba flanqueada por sendas columnas (Fig. 3). A un lado estaba aún in situ una gran losa adosada a la pared, que serviría de pedestal a uno de esos elementos sustentantes, y junto a la misma apareció un tambor del fuste, derrumbado en esta cámara. Sus dimensiones son $62 \mathrm{~cm}$ de largo por

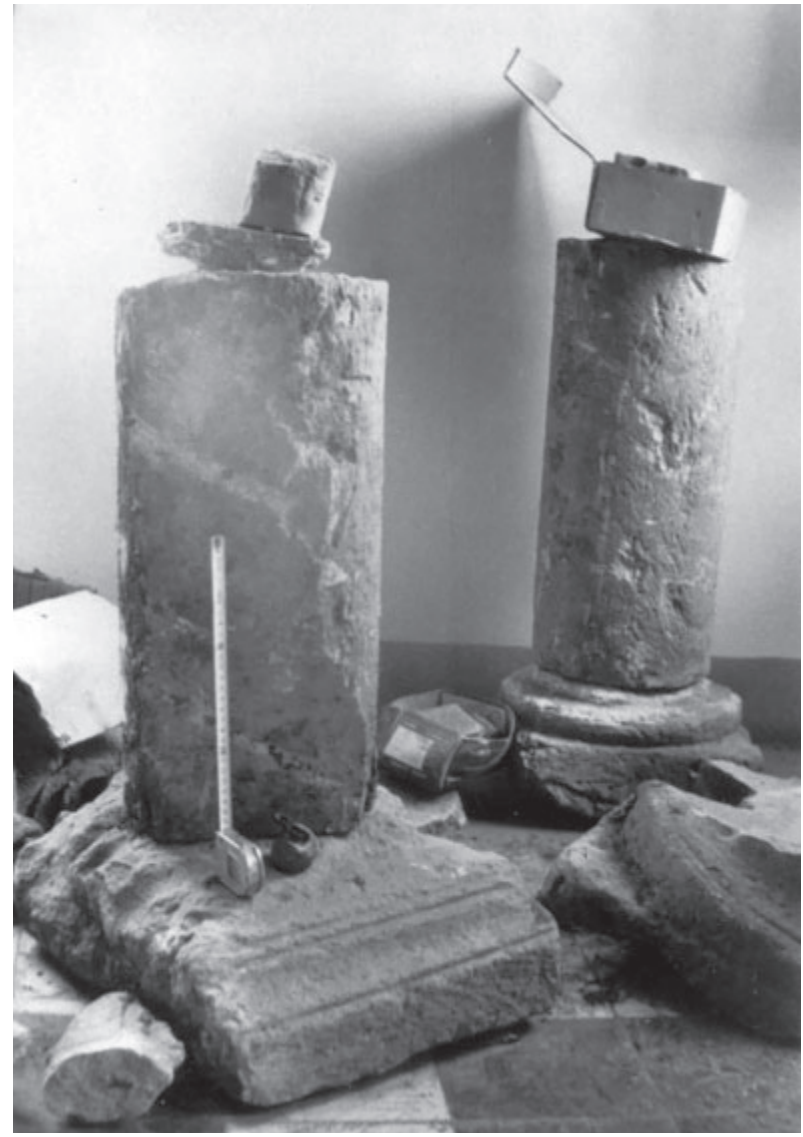

Figura 13: Fragmentos de columnas. Foto: Puig y Montanya (MP de Ciudad Real).

$22 \mathrm{~cm}$ de diámetro. Fue tallado en un único bloque de piedra arenisca local y es liso. A menos de medio metro se descubrió una basa de columna del mismo material, que probablemente estaba en el otro flanco y es tipológicamente muy similar a otras localizadas en sus inmediaciones (concretamente en el porche). En la zona oriental de éste se disponía otra basa a la altura de la habitación $\mathrm{n}^{\circ}{ }^{\mathrm{O}} 12$, desplazada de su lugar originario. Tiene un plinto cuadrado que mide $29 \mathrm{~cm}$ de lado por $11 \mathrm{~cm}$ de alto y dos molduras circulares, el toro, de $5 \mathrm{~cm}$ de alto, con un diámetro de $29 \mathrm{~cm}$, y el himoscapo, de 3,5 cm de alto, que tiene un diámetro de $25 \mathrm{~cm}$. Junto a un acceso inhabilitado de la habitación n. 28 se encontró una basa de columna, movida, cuyo plinto cuadrado mide $33 \mathrm{~cm}$ de lado por $10 \mathrm{~cm}$ de alto, con dos molduras circulares superpuestas, la altura del toro es de $4 \mathrm{~cm}$ y la del himoscapo, $7 \mathrm{~cm}$, con un diámetro de $23 \mathrm{~cm}$. En el centro de esta sala hay una basa conservada in situ, cuyo plinto mide $38 \mathrm{~cm}$ de lado por $17 \mathrm{~cm}$ de alto, el toro tiene una altura de $6 \mathrm{~cm}$ y el himoscapo, $2 \mathrm{~cm}$, con un diámetro de $26 \mathrm{~cm}$. Es, por tanto, ligeramente mayor que las restantes. Está alineada con los muros de la primera fila de habitaciones que confinan con el pórtico. Seguramente soportaría una viga de carga. Otra basa de columna, que en esta ocasión no se hallaba en su emplazamiento primitivo, estaba junto al muro oeste, en línea con el correlativo 
ambiente n. ${ }^{\circ}$ 13. Su plinto mide $31 \mathrm{~cm}$ de lado por 10 $\mathrm{cm}$ de alto, el toro, $3,5 \mathrm{~cm}$ de alto y el himoscapo, 3,5 de alto por $22 \mathrm{~cm}$ de diámetro. A su vez, en la zona de paso a la habitación $n^{\text {o }} 33$ había una basa de columna caída, cuyo plinto mide $31,5 \mathrm{~cm}$ de lado por $4 \mathrm{~cm}$ de alto, el toro tiene una altura de $3 \mathrm{~cm}$ y las dimensiones del himoscapo son: $2 \mathrm{~cm}$ de alto y un diámetro de $23,5 \mathrm{~cm}$. Del mismo modo, en la puerta por la que se realizaba el tránsito desde el pasillo 31 a la habitación 39 se documentó una basa de columna y un capitel. Probablemente procedían de dicha galería n. ${ }^{\circ} 31$, que sería un espacio porticado. La basa estaba desplomada en la misma entrada, a la altura de la cara exterior del muro occidental. El plinto cuadrado mide $33,5 \mathrm{~cm}$ de anchura máxima por $20,5 \mathrm{~cm}$ y $9 \mathrm{~cm}$ de altura, el toro tiene $4,5 \mathrm{~cm}$ de alto y el himoscapo, un diámetro de 21 $\mathrm{cm}$ por $7 \mathrm{~cm}$ de alto (esto es, una altura total de 20,5 $\mathrm{cm})$. En cuanto al capitel, del que ya hemos dado algunos detalles más arriba, estaba desplomado en línea con la basa y con el citado muro oeste.

En algunos puntos del conjunto doméstico encontramos vestigios de los referidos tabiques de adobe o restos de los mismos entremezclados en el nivel de derrumbe, p. ej., a la entrada de las habitaciones 8 y 33, en la 19 u ocluyendo algunos vanos, como el de una antigua puerta de la habitación 12. Ocasionalmente fueron erigidos en función de alguna reforma ulterior, pero, por lo general, completaban el alzado de los muros, a veces apoyados directamente sobre los zócalos de piedra u otras superpuestos a tongadas de ladrillos empleadas para proporcionar una base regular encima de los mampuestos, de modo que el remate de las estructuras se realizaría con adobes, sistema bastante común durante la Antigüedad Tardía, al igual que lo fue el paramento de tapia terriza. A diferencia del opus testaceum, esos muros terreros han desaparecido.

Un pasaje de Varrón (rust. I, 14, 4) nos ilustra elocuentemente sobre la construcción de tapias de tierra mediante encofrados y de un texto de Plinio $(\mathrm{NH}$ XXXV, 14-4) se deriva que estaba muy extendida en Hispania (acerca de la construcción encofrada, cfr. Choisy, 1873/1999, 18-19).

Por consiguiente, la obra de Puente de la Olmilla consiste básicamente en una combinación de piedra, tierra, cal y arena, materiales fácilmente disponibles. De los aparejos destacarían sobre todo las potentes cimentaciones de mampuesto, cuya anchura es de unos 0,70 m de media. Algunos de los zócalos alcanzan una altura de unos 0,50 m. En cambio, de algunas de las estructuras meridionales apenas quedan los fundamentos de piedra, que han sufrido un arrasamiento notable. Este sector del edificio, profundamente dañado por las modernas vertederas de los tractores y la plantación de olivos, ha sido mínimamente excavado, por lo que no se ha podido determinar su disposición y tampoco podemos señalar nada sobre la finalidad que cumplía.

El análisis de los paramentos nos ha permitido advertir que no todos ellos son contemporáneos. En una fase de ocupación bastante tardía se levantaron algunos muros de distinta factura y escasa calidad, que presentan gran cantidad de fragmentos de tegulae e imbrices intercalados entre los mampuestos. La reutilización de esos materiales delata una larga ocupación de la villa. Las diferentes técnicas constructivas, entre otros indicios, denotan algunas remodelaciones y ampliaciones del proyecto arquitectónico inicial. Llevadas a cabo en diversos lugares de la vivienda, determinaron cambios puntuales en ella, en función de las necesidades surgidas a lo largo de la vida de sucesivas generaciones de propietarios y también de sus gustos, adaptados a las modas urbanas imperantes durante el Bajo Imperio, en congruencia con el concepto de urbanitas anhelado por las élites provinciales, muchos de cuyos miembros se habían trasladado al campo. Los añadidos realizados sobre la primera planta de la villa no supusieron una transformación radical de la misma, sino que, a juzgar por los resultados de las excavaciones, en lo esencial ésta fue bastante respetada, obedeciendo, parece ser, a un plan continuista, en cuyo transcurso se fue moldeando formalmente.

En cuanto a los ladrillos, habitualmente aparecieron entremezclados con el restante material procedente del derrumbe de la villa, por lo que buena parte de ellos no estaban enteros. Tan sólo eventualmente se hallaron in situ, p. ej., en el suelo de la habitación 12, junto a la puerta de la n. ${ }^{\circ} 34 \mathrm{y}$ de la n. ${ }^{\circ} 35$ o en la entrada de la $\mathrm{n}^{\circ}{ }^{\mathrm{o}} 25$, asimismo, hay varios cohesionados con mortero en la última hilada conservada del zócalo septentrional del pórtico exterior (n. $\left.{ }^{\circ} 13\right)$, consistente en una capa colocada uniformemente sobre la sólida base de mampostería, seguramente con objeto de nivelarla. Son un testimonio de la técnica constructiva romana que permitía regularizar las hiladas de piedra con verdugadas de ladrillo, por lo general para recrecer el muro con adobe. Con todo, los ladrillos documentados son insuficientes para analizar la regularidad de los paramentos. No nos es posible, por tanto, describir más exhaustivamente las características del aparejo de Puente de la Olmilla, al estar derruidas las zonas medias y altas de sus estructuras. Únicamente se conserva algo más del alzado de las pertenecientes a los pasillos n. ${ }^{\circ} 31$ y 32 , en una altura que ronda 0,50 $\mathrm{m}$. Por lo demás, debemos tener en consideración que posteriormente el yacimiento ha servido como cantera de aprovisionamiento de materiales, provocando esto la pérdida de muchos de sus elementos constructivos.

Como pauta morfológica, se utilizaron ladrillos rectangulares y de dimensiones dispares, en todo caso, menores que los estándares del bipedalis (de 59,2 $\mathrm{cm}$ de lado, esto es, dos pies romanos). Es de notar que no hemos constatado la existencia de ninguno cuadrangular.

En el registro arqueológico de Puente de la Olmilla figura un gran número de estas piezas cerámicas y contamos con muchas variantes tipológicas, de manera que no podemos hablar de un «ladrillo tipo», por ese motivo, como era predecible al tratarse de una villa rustica, resulta difícil establecer un patrón, unos 

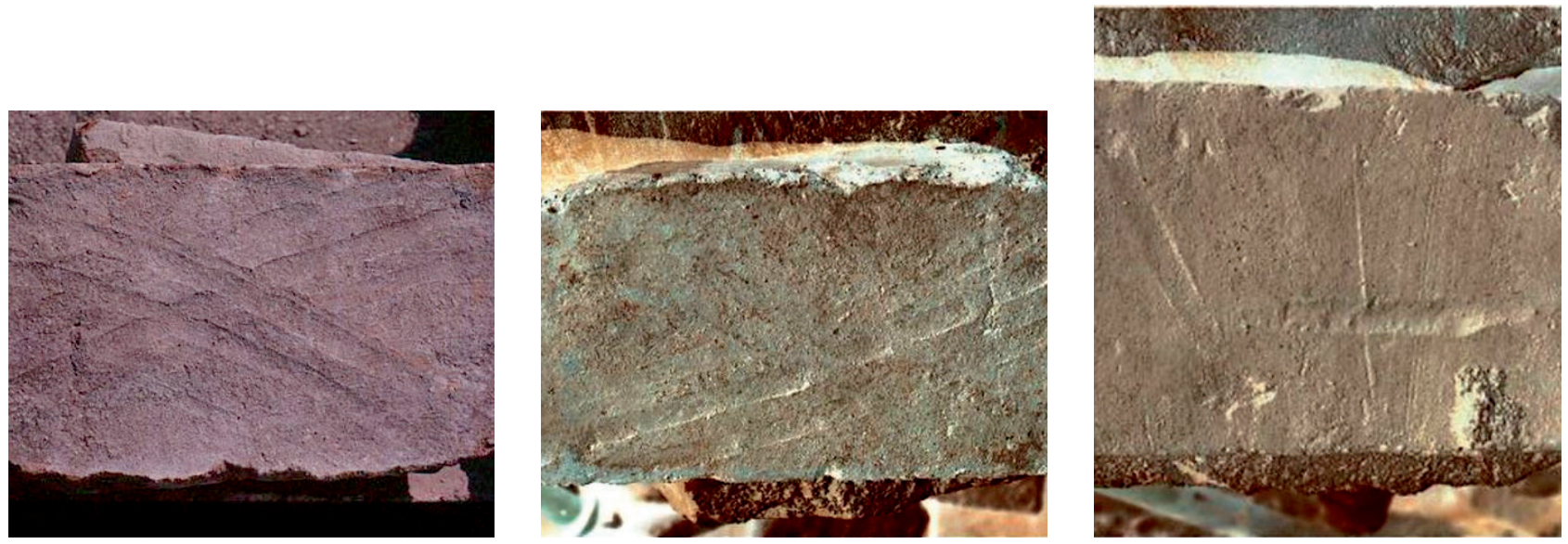

Figuras 14-16: Ladrillos con digitaciones. Foto: García Bueno.

cánones similares a los mencionados en un ensayo de L. Roldán (1987, 101-122), basados en los rasgos distintivos de los ladrillos y los morteros de los edificios de algunas ciudades de la Península Ibérica. Esta autora tampoco pudo reconocer una secuencia cronológica ni una tipología válida para todo el territorio peninsular, debido a la carencia de sellos y a la diversidad de los ladrillos según su procedencia, llegando a la conclusión de que ciertas diferencias técnicas, como la cantidad de pasta en la composición de cada ladrillo o el proceso de cocción, secado y cortado, pudieron influir en la alteración de sus dimensiones, a pesar de que se utilizaban moldes. Asimismo, esta investigadora ha comprobado que suelen ser más regulares los módulos de los ladrillos en edificios públicos que en los privados, como es el aquí estudiado.

Así pues, las medidas de los ladrillos de Puente de la Olmilla no son homogéneas, además, al estar muchos de ellos fragmentados y, en consecuencia, encontrarse incompletos los bordes, sus proporciones pudieron ser mayores, como en el caso de algunos de los descubiertos al excavar la galería de fachada (merece destacarse que algunos otros, in situ, no estaban fraccionados). Tan sólo por enumerar algunos de los recuperados en otras zonas, diremos que los hay de 48-50 cm de largo por 16 ó $32 \mathrm{~cm}$ de ancho, con un espesor de $4 \mathrm{~cm}$. Varios de los aparecidos en la habitación 22 tienen un módulo diferente: miden $32 \mathrm{~cm}$ de largo por $27 \mathrm{~cm}$ de ancho y su grosor es de $5 \mathrm{~cm}$. También en el departamento 39 hay alguno de $32,1 \times 26,5 \times 3,8 \mathrm{~cm}$, mientras que otros miden 48 x 32,2 x $5 \mathrm{~cm}$ y en la habitación 28 se tapió un vano con piezas latericias de $33 \mathrm{x}$ $26,5 \times 6 \mathrm{~cm}, 32 \times 27 \times 6 \mathrm{~cm}, 52 \times 31 \times 6 \mathrm{~cm}$, etc. En la habitación 12 salió a la luz un suelo embaldosado con grandes ladrillos de forma rectangular, cuyas medidas son $50 \mathrm{~cm}$ de largo por $35 \mathrm{~cm}$ de ancho, con un grosor de $4 \mathrm{~cm}$. En otra dependencia, la n. ${ }^{\circ} 34$, se conservan in situ dos ladrillos, colocados sobre el suelo, a un lado de la puerta, que miden $58 \mathrm{~cm}$ de largo por $33 \mathrm{~cm}$ de ancho y $6,5 \mathrm{~cm}$ de espesor; igualmente, otro, de $49 \mathrm{x}$ 32 x 5,5 cm, se dispone de modo similar junto a un muro de la habitación n. ${ }^{\circ} 35$, sobresaliendo del solado.
Varias baldosas de barro rectangulares pavimentaban el pasillo n. ${ }^{\circ} 32$, al menos parcialmente, dándose así un uso secundario a los ladrillos. En resumen, pese a la manifiesta disparidad de sus módulos, un alto porcentaje de ellos se ajusta a una medida que oscila entre 48 y $52 \mathrm{~cm}$ de largo, siendo más variable el ancho; con todo, no resulta posible reconocer una seriación tipológica de los mismos y, como era previsible, ninguno sigue los módulos normalizados en Roma (Adam, 1996, 159; Lugli, 1957; Hoffman, 1975, 111-120; sobre el tema de los ladrillos romanos resulta de gran interés el trabajo de Bendala, Rico y Roldán, 1996).

Plinio (NH XXXV, 170) describe tres tipos de ladrillos, pero durante la baja romanidad ya se había perdido esa idea del módulo, por lo que no sería posible extrapolar aquí dicha tipología, máxime teniendo en cuenta que estamos en un contexto territorial provincial situado en uno de los confines del Imperio y, por añadidura, en el medio rural. En plena coherencia con esta premisa está el estudio de los de la villa de El Saucedo (Castelo et alii, 1997, 72-73).

Aunque comúnmente «se recurría al sistema metrológico para facilitar la tarea del albañil» (Adam, 1996, 64), los materiales de construcción se fabricaban según las costumbres locales. Cabe suponer que los domini de Puente de la Olmilla encargarían producciones de esa clase para su casa de campo (a no ser que contaran con un alfar propio, de cuya existencia, al menos hasta la fecha, no hay indicios arqueológicos). En Hispania había numerosos talleres locales especializados en materiales constructivos y anfóricos e incluso en algunas villae se han encontrado alfarerías anejas, como, p. ej., J. C. Serra Ráfols $(1952,26)$ sugiere que ocurría en La Cocosa y en muchas otras «fincas romanas». Dependientes de varias de las villae del Duero, había tejares dedicados a su fabricación, uno de los cuales fue excavado en las proximidades de la de Requejo (Zamora), y eran usuales los hornos cerámicos en las partes rusticae de algunas como las de Navatejera y La Olmeda (Regueras, 2013, 48-49). En estos casos, los centros de producción estarían en los propios lugares de consumo. 
Por todo lo expuesto, no es factible establecer una sistematización cronológica y formal del ladrillo en el ámbito peninsular (Bendala, 1992, 222), al contrario que sucede en Roma (Lugli, 1957). Según A. García y Bellido (1979, 50-52), hasta época antoniniana el grosor medio de los ladrillos era de 2 a $3 \mathrm{~cm}$ y posteriormente fue aumentando, llegando a ser de unos $5 \mathrm{~cm}$ en tiempos de Diocleciano y Constantino. El espesor de los de Puente de la Olmilla oscila entre 4 y 6,5 cm.

El color de la pasta de las piezas recuperadas no es exactamente uniforme, pudiendo haber sido alterado tanto por algunas particularidades de su proceso de elaboración como por las condiciones atmosféricas. A grandes rasgos, suelen ser de color ocre claro y estar bien cocidas. Con frecuencia presentan marcas digitales (Figs. 14-16), que son de distintos tipos: las más comunes son líneas entrecruzadas en el centro formando aspas, casi siempre trazadas con tres dedos, o bien un zig-zag realizado con dos dedos unidos, también hay líneas rectas u onduladas, que a veces se cruzan en el centro, etc. En todos los casos fueron dibujadas con los dedos en el barro aún fresco. No hemos documentado marcas realizadas después de la cocción, ni tampoco el sello de ninguna officina.

\section{LA CUBIERTA Y LOS PAVIMENTOS}

En casi todos los ambientes excavados en Puente de la Olmilla aparece un nivel de derrumbe compuesto por gran cantidad de cerámica constructiva (tejas, tanto planas como curvas, ladrillos, etc.), fragmentos de estuco, cal, argamasa, ripios, numerosos clavos...

Así pues, la techumbre (Fig. 17) estaba mayoritariamente formada por un armazón de madera claveteada y, sobre él, tegulae e imbrices, utilizadas para su impermeabilización y muy abundantes en todo el yacimiento (a propósito de los elementos de cubrición, cfr. Adam, 1996, 230-232). Prácticamente en su totalidad estaban tan fragmentadas que no fue posible medirlas, salvo una imbrex que apareció entera (en la puerta de la habitación $n .^{\circ} 17$, por donde se comunicaba con la galería n. ${ }^{\circ}$ 5), cuyas dimensiones son 58 x $27 \mathrm{~cm}$. En la habitación $\mathrm{n}^{\circ}{ }^{\circ} 2$ se recogió un gran fragmento de tegula de 34 x $32 \mathrm{~cm}$ y $5 \mathrm{~cm}$ de grosor, que en su origen mediría, al menos, $48 \mathrm{~cm}$ de largo, y otro fragmento de $32 \times 27 \times 16 \mathrm{~cm}$, con un grosor de $4 \mathrm{~cm}$. Algunas de ellas tienen marcas digitales, tales como líneas entrecruzadas en un extremo. Eventualmente, alguna estaba quemada, p. ej., en el patio, donde hay un potente nivel de incendio, apenas detectable en otras zonas.

En su estudio de síntesis sobre las villae del Duero, F. Regueras (2013, 50-51) advierte que son raras aquéllas en las que se confirma el empleo de ambos tipos de teja simultáneamente (tegulae e imbrices), siendo más usual la curva, y evoca un pasaje de San Isidoro (Etimologías 19.10.15), que traemos a colación: «Tegulae vocatae quod tegant aedes, et imbrices quod accipiant imbrex».

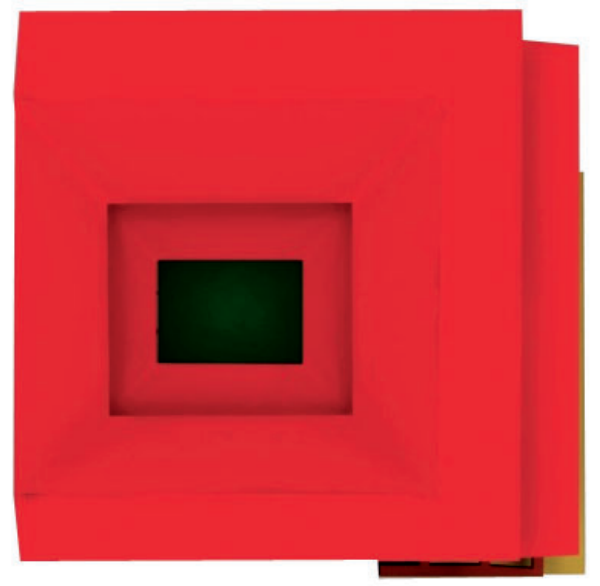

Figura 17: Propuesta de reconstrucción virtual de la cubierta, según García Bueno. Imagen cedida por el MP de Ciudad Real.

En lo que respecta a la carpintería de armar (Adam, 1996, 222-230, 233), no tenemos ningún indicio del procedimiento usado en Puente de la Olmilla. Únicamente se han conservado pequeños fragmentos de madera carbonizada, muchos de los cuales pertenecerían a las vigas y el resto de la estructura sobre la que descansaban las tejas.

Las referencias relativas a esta cuestión proporcionadas por los autores antiguos son muy imprecisas o están incompletas (Choisy, 1873/1999, 125, nos facilita una breve relación de las mismas). Tan sólo contamos con descripciones de algunas armaduras de madera, que podrían resultarnos ilustrativas, pese a corresponder a lugares geográficamente distantes, como es el caso de una cubierta toscana o la de un cobertizo de Pozzuoli (Fig. 18), de las que sí se conocen los métodos o programas mediante los que se organizaban las piezas de la techumbre (Choisy, 1873/1999, 125-143, figs. 85, 86 y 96). Tiene especial interés la restitución que nos ofrece A. Choisy (1873/1999, 143, fig. 96) de un tipo de cubierta «frecuentemente utilizado en la antigüedad romana», pudiendo servirnos de referente, al menos a modo de hipótesis de trabajo.

El desplome del tejado, tras quedar deshabitada la villa, provocó el deterioro o destrucción de algunas de las superficies de circulación, p. ej., las de las habitaciones n. ${ }^{\circ} 19,22$ y 39, donde los fragmentos del opus caementicium se hallaron entremezclados con los restantes materiales de derrubio, pero, ocasionalmente, la gruesa capa de tejas que cubrió la mayoría de los ambientes sirvió de protección de agresiones posteriores, hasta que comenzó la actividad de los tractores, cuyas potentes rejas de arado arrancaban a su paso mosaicos, muros...

Por lo demás, como es típico en la arquitectura doméstica romana, uno de los pocos espacios sin techar fue el patio, en función del que se concibe y ordena esta edificación de carácter residencial, centralizando el circuito de acceso a diversas dependencias aglutinadas a su alrededor. Por medio de la galería porticada 


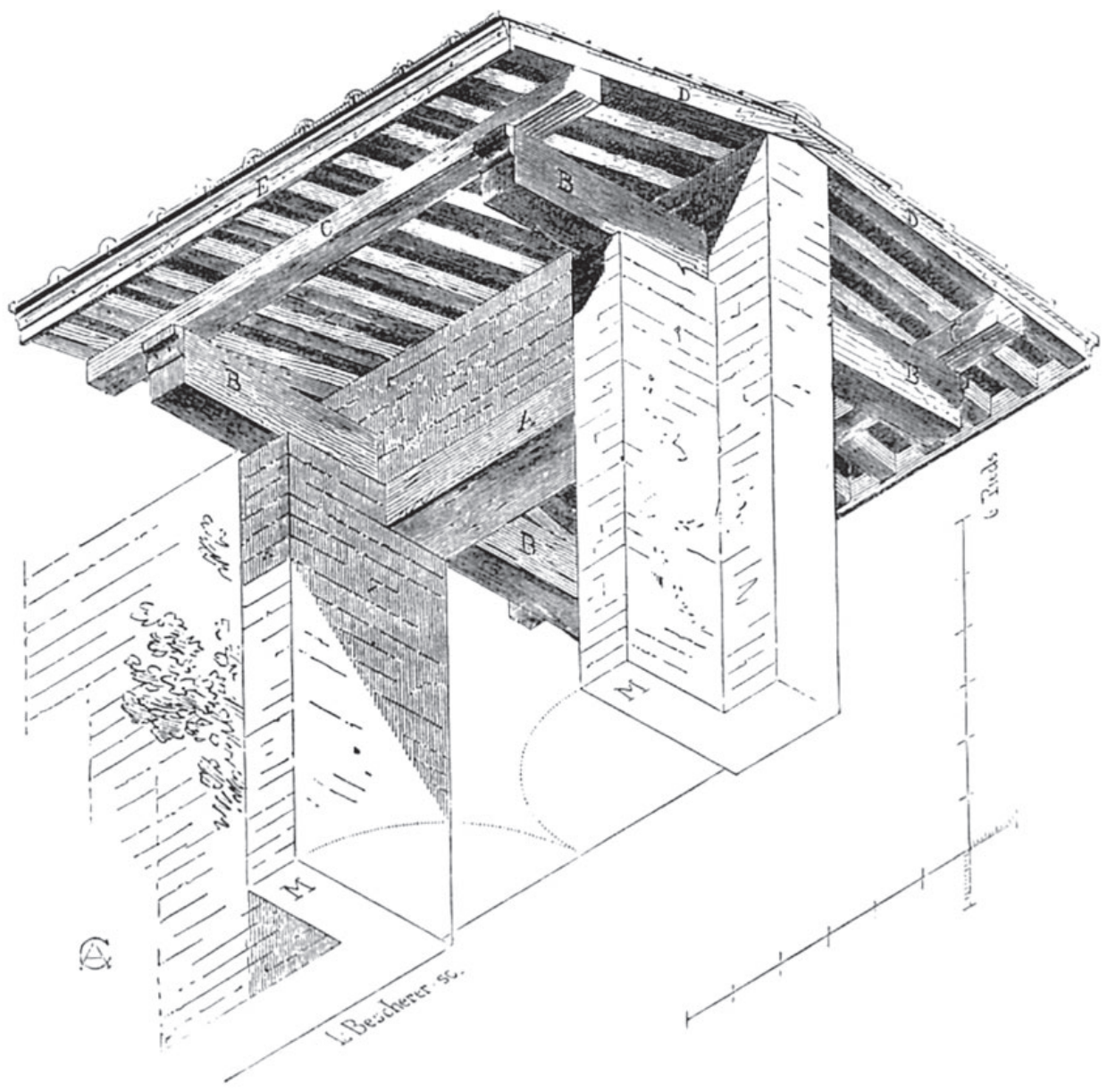

Figura 18: Restitución hipotética de la cubierta de un cobertizo de Pozzuoli, según Choisy, 1873/1999, 126, fig. 85.

en la que se inscribe se facilita la comunicación e interrelación entre ellas. Convertido en eje que estructura buena parte de esta vivienda, constituye la principal fuente de luz y aireación de las habitaciones interiores de la misma.

Para erigirla, sus constructores se surtieron fundamentalmente de materias primas procedentes de los contornos (arcilla, yeso, piedra calcárea y silícea de las canteras locales, etc.), relativamente fáciles de extraer y de trabajar, siendo muy exiguos los materiales foráneos cuya presencia ha sido constatada, tales como algún pequeño fragmento de mármol, claramente insuficiente para poder saber si alguna de las superficies estaba revestida por placas marmóreas (sectilicia parietales...) o corresponde a algún enser realizado en mármol. Como argumenta L. Roldán $(1987,101)$, la elección de los materiales y de las técnicas constructivas suele estar relacionada con los sucesos históricos y los condicionamientos técnicos locales. A ello hay que añadir el poder adquisitivo del cliente, el dominus, habida cuenta del alto precio que tenía esta clase de importaciones. J.-G. Gorges $(1979,151)$ contrapone la lujosa decoración interior de las villae hispanas a la pobreza de los materiales empleados en «el cuerpo de los edificios» de la mayoría de estos hábitats rurales. Obviamente, era más económico proveerse de materiales que estaban «a mano», que acarrear otros desde largas distancias.

Por ese motivo, en Puente de la Olmilla se utilizó fundamentalmente barro cocido, pizarra y piedras calizas de la zona para fabricar las teselas con las que fueron confeccionados los mosaicos pavimentales, aunque el resultado fuera un colorido no demasiado extenso. De ello se desprende un intento de economizar en su producción, que parece ser local, a tenor de lo expuesto. El variado repertorio musivo, de impecable factura, destaca especialmente en cuanto a las características ornamentales de la villa, siendo una de las principales manifestaciones de su cultura material (García Bueno, 1994, 95-116; 2000, 191-203; 2001, 212-217). Estos mosaicos son de estilo geométrico, a excepción de un panel con el emblema de dos felinos localizado en la habitación 2 y otro figurativo, con el tema de los Cuatro Vientos, que tapizaba la habitación 4, lamentablemente arrasado un tiempo después de salir a la luz. Además, se han documentado numerosos pisos de opus caementicium, restos de un opus signinum en la habitación $\mathrm{n} .^{\circ} 15$, un opus spicatum en una sala con columnas (n. $\left.{ }^{\circ} 45\right)$, enlosados de baldosas de barro en un compartimento y un corredor (n. ${ }^{\circ} 12$ y 32 , respectivamente). Los restantes suelos son de tierra batida, lo que induce a pensar en una dedicación a fines 
utilitarios (de servicio o de almacenaje) de los departamentos donde aparecieron. Por consiguiente, se hace patente una jerarquía funcional de los pavimentos.

\section{LA DECORACIÓN PICTÓRICA}

Antes de colocar los lienzos de mosaico se enlució y pintó los paramentos. Al ser extraídos algunos de aquéllos se pudo observar que la preparación de la pintura quedaba «ligeramente por debajo de los mismos» (Puig, 1979, 924), superpuestos al rudus.

La villa ofrecería un aspecto bastante elegante, a juzgar por los pavimentos musivos y las pinturas murales, que enriquecían notablemente el programa decorativo de la pars urbana. Combinadas con los mosaicos, a los que estaban asociadas, conferían al conjunto un variado cromatismo. En efecto, en ellas se empleó una paleta de colores base tales como el azul, rojo, amarillo, verde, gris, rosa, blanco, negro... (algunas consideraciones sobre estos temas, en Barbet, 1983, 43-53; 1990, 255-271). Según permiten inferir los datos proporcionados por el registro arqueológico ${ }^{6}$ de este yacimiento, las paredes de los espacios residenciales no estaban recubiertas de placas marmóreas (su uso solía ser frecuente en las salas termales y en algunas de las de aparato). Dado el elevado coste que habría tenido la adquisición de este material lapídeo, se optó por uno mucho más modesto: el estuco, imitando puntualmente esa lujosa decoración arquitectónica mediante pinturas murales de estilo crustae o «falso mármol». La mayoría de las planchas de estuco pintado aparecieron desprendidas del soporte original, fragmentadas o muy deterioradas, no obstante, se conservaban in situ algunos paneles con un revoco pintado, a nivel del zócalo. Debido a ello sabemos que dentro de su repertorio temático había simulaciones de piedras ornamentales y de ricos mármoles. Además de las crustae marmóreas, se plasmaron diversos motivos geométricos (hasta la fecha no contamos con ningún testimonio de elementos figurativos), pero, por su estado fragmentario, sólo se ha logrado identificar muy parcialmente el desarrollo de esa decoración pictórica, de la que apenas quedaban huellas cuando empezamos a excavar este yacimiento. Por esa causa ignoramos si en ambos soportes (pintura parietal y pavimentos musivos) se reprodujeron eventualmente algunos de los motivos de repertorio, dándoles una continuidad decorativa a paredes y suelos, como sucedía en otras unidades domésticas, que los compartieron, p. ej., en la villa murciana de La Quintilla (Ramallo, 2005, 1019). Ello nos impide estudiarlos de manera interrelacionada.

6. ${ }^{6}$ Con la salvedad de un pequeño fragmento de laja de mármol blanco descubierto en el patio, del que desconocemos su disposición originaria, pero que podría haber sido utilizado en el revestimiento de alguna de las superficies (¿el zócalo, p. ej.?).
Algunas de las piezas molduradas de estuco halladas en varios departamentos entremezcladas con los materiales de derrubio, corresponderían a cornisas que remataban la parte alta de las paredes, en su unión con el techo, y otras son indicativas de la existencia de rodapiés de estuco pintado que embellecían la zona inferior de los muros, en contacto con el suelo (aunque no tendrían un carácter propiamente decorativo, sino funcional, para ocultar la unión entre el piso y el paramento). Por poner algún ejemplo, se constató la presencia in situ de las molduras estucadas del rodapié en la habitación $n^{\circ} 26 \mathrm{y}$, a su vez, la habitación n. ${ }^{\mathrm{o}} 2$ tenía un rodapié en forma de semi-toro, de unos $20 \mathrm{~cm}$ de ancho.

El revestimiento interior de estuco pintado con una amplia gama cromática contribuiría a dar mayor realce y suntuosidad a muchas de las dependencias, pues es digno de reseñar que no sólo estaban pintadas las estancias de representación social, aunque, como sucedía con frecuencia en las casas romanas acomodadas, posiblemente variara el tipo de decoración en función de la categoría de los ámbitos (lisa, con recreaciones de mármoles u otras composiciones; a propósito de esta cuestión, cfr. Abad, 1977-78, 189; Novello, 2003, 356-360; Chavarría, 2007, 108), recalcando de ese modo su diverso rango, tal como comenta Vitruvio (De Arch. I, 2,5).

En uno de los recintos de la villa de Albaladejo, el n. ${ }^{\circ}$ 9, quedaba aún en pie parte del enlucido $\mathrm{y}$, a su vez, se recogieron algunos fragmentos de desigual tamaño con restos pictóricos (de colores amarillo, línea blanca sobre fondo amarillo, línea blanca sobre fondo rojo burdeos...). Se trataba de una pintura de muy buena calidad, con dos capas de preparación. En la habitación n. ${ }^{\circ} 2$ aparecieron numerosos fragmentos policromos de estuco parietal (en rojo, negro y amarillo; el arranque de los muros estaba revestido de estuco pintado de rojo) e incluso se pudo reconocer uno con apariencia de piedra. Gracias a la combinación de esas fuertes tonalidades del revestimiento parietal y el luminoso colorido del pavimento musivo se lograría un vistoso efecto en este aposento, que lo haría resaltar especialmente.

Entre las llamadas imitaciones de crustae (cuyo espectro no se reduce al mármol propiamente dicho), R. Hidalgo $(1990,113)$ presta atención a las rocas nobles, dado que se utilizaban también en la arquitectura romana para recubrir las estructuras. Estudia este autor las distintas técnicas pictóricas empleadas en la ornamentación de la villa cordobesa de El Ruedo (Hidalgo, 1990, 113-119). Una de ellas, la que simula el mármol moteado, se ejecutó igualmente en el departamento n. $^{\circ}$ 17 de Puente de la Olmilla, donde, con una brocha o pincel impregnado de pintura se realizaron aspersiones sobre un fondo liso. Este recurso se puso en práctica en las dos capas sucesivas documentadas: inicialmente, en toda la superficie preservada de la primera de ellas, de una tonalidad gris, con salpicaduras en blanco y negro; después, cuando se procedió a renovar su 


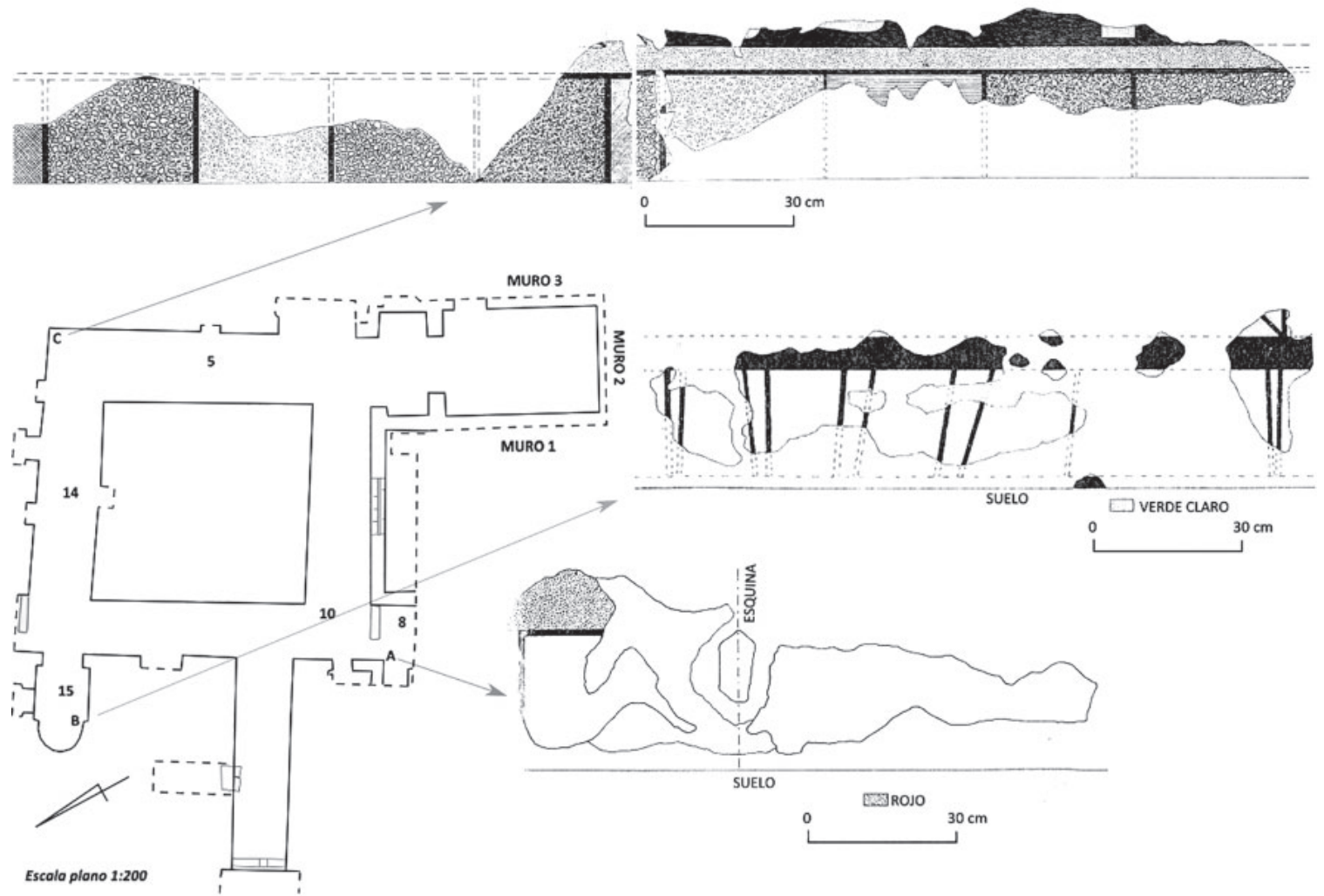

Figura 19: Decoración parietal de Puente de la Olmilla. Dib.: Elaboración propia, a partir de Puig Ochoa, 1979, 923-930.

decoración en una etapa más avanzada, se aplicó una segunda capa (de $0,5 \mathrm{~cm}$ de espesor), reservándose el fondo de color gris, con moteado en blanco y negro, al zócalo, cuyo límite superior fue fileteado en negro. El friso fue pintado en un rosa intenso, salpicado en blanco y negro. Asimismo, esta solución decorativa se utilizó en alguno de los lienzos parietales de los corredores que bordean el patio interior. También el zócalo de una de las salas de la villa de La Quintilla (Lorca, Murcia) tiene una decoración marmórea a base de moteado (Ramallo, 2005, 1015-1016; sobre las pinturas de este complejo doméstico, cfr. Plaza, García Sandoval, Fernández Díaz, Martínez Rodríguez, Ponce y Ramallo, 2003-2005, 247-262; en general, acerca del mármol moteado en Hispania, Guiral, Mostalac y Cisneros, 1986, 259-288).

En lo que concierne al porche de entrada (n. $\left.{ }^{\circ} 13\right)$, su decoración consistía en una banda negra (de $5 \mathrm{~cm}$ ) con una franja blanca atravesada por grupos de tres líneas negras separados en torno a $20 \mathrm{~cm}$ uno de otro (cada trazo medía unos $2 \mathrm{~cm}$ de ancho). El zócalo estaba delimitado por dos líneas negras sobre fondo blanco, con unos pequeños dibujos en negro. Por encima de esos dos trazos lineales negros la superficie central del paramento era de color blanco.

En la habitación n. ${ }^{\circ} 35$ se combinaron los colores negro, verde y blanco sobre fondo rojo burdeos.

Algunas paredes de la casa fueron pintadas en un tono monocromo, otras simplemente serían cubiertas con una capa de cal, de la que tenemos profusa constancia arqueológica en el yacimiento. La habitación n. ${ }^{\circ} 4$ es el único ejemplo en el que está representado el color azul en una amplia superficie. Su excavación reveló que las placas de estuco, con restos de pigmento azul, estaban desplomadas sobre el piso de mosaico, a consecuencia del derrumbe de los muros.

M. R. Puig (1979, 923-930) analizó estilísticamente y clasificó algunos restos encontrados en la campaña de 1976, pero, desafortunadamente, la mayoría de los que permanecían en su ubicación primitiva ya se habían perdido casi en su totalidad cuando nos hicimos cargo de la intervención arqueológica años más tarde (al estar insuficientemente protegida, la pintura mural había desaparecido por efecto de las lluvias y demás inclemencias climatológicas), sin que se hubieran publicado testimonios gráficos de ese conjunto pictórico (tan sólo se incluyeron en dicha publicación algunos dibujos de las tres zonas a que se hace referencia en el texto; pese a no haber ilustraciones, es el único documento con que contamos para su estudio y por esa razón los reproducimos aquí). Nos remitimos, por tanto, al examen que M. R. Puig acometió y dio a conocer en dicho trabajo. En el ángulo de contacto entre los ambientes n. ${ }^{\circ} 9$ y 24 (A, en el plano adjunto, Fig. 19) había vestigios de pintura mural, bastante perdida. Originariamente se pintó de blanco, pero más adelante se aplicó sobre ella una decoración consistente en un zócalo blanco con un cuadrado o rectángulo en negro. En el registro superior a éste había un friso corrido de color rojo. El espesor de la preparación de 
las dos capas de pintura era de $1,5 \mathrm{~cm}$ por término medio, cada una.

También la habitación n. ${ }^{\circ} 15$ (B en el plano adjunto, Fig. 19) estuvo en un principio pintada por entero de blanco y posteriormente se superpuso en el zócalo una composición de bandas en alternancia cromática: una en negro, otra blanca cruzada por rayas negras oblicuas y, a modo de límite intermedio, otra franja negra. Más arriba, la sección central del lienzo de pared fue decorada con líneas negras sobre un fondo verde claro. La preparación previa de esta pintura adolecía de una calidad bastante defectuosa, de ahí su pésimo estado de conservación.

La intervención arqueológica nos ha deparado, por tanto, pruebas de la existencia de dos fases pictóricas, lo que supone la constatación material de la renovación de su programa decorativo en distintos momentos.

Según M. R. Puig (1979, 924), los pórticos del peristilo estaban decorados con diversos esquemas de diseño, de los que sólo se había preservado, relativamente bien, la zona inferior (I), esto es, el zócalo. En la esquina de los pasillos n. ${ }^{\circ} 5$ y 14 (C en el plano adjunto, Fig. 19) había una serie de «rectángulos más o menos regulares con imitaciones de piedras duras o crustae» de viva policromía: círculos de colores verde claro y rojo sobre fondo amarillo; círculos en rojo sobre un fondo igualmente amarillo (imitando el «giallo antico»); fondo de un tono rosa intenso o violeta con motas blancas; fondo blanco salpicado en negro; fondo rojo con salpicaduras en negro. Todos estos paneles estaban divididos por líneas verticales negras y, a su vez, separados del friso superior mediante una franja en rojo y negro. En la zona II quedaban indicios del uso de los colores verde claro, negro y blanco.

Por lo demás, los fragmentos de estuco pintado rescatados durante las campañas que, por nuestra parte, llevamos a cabo años después, fueron depositados en el Museo Provincial de Ciudad Real.

Es de subrayar que los sistemas compositivos descritos son bastante comunes en la decoración pictórica romana a partir del siglo I (puede consultarse, al respecto, Abad, 1982, 189-208; Guiral, Mostalac y Cisneros, 1986, 259-288; Mostalac, 1992, 9-22).

La representación de lajas de mármol con veteados, bandeados, moteados o círculos y óvalos de diversos tipos, tamaños y tonalidades, que imitaban el mármol jaspeado o el brocatel «es algo consustancial a la pintura romana» (Abad, 1977-78, 189). L. Abad puntualiza que entre los restos conservados en Hispania abundan las tres variedades, adscritas fundamentalmente a los zócalos, aunque las simulaciones de mármol jaspeado y el brocatel en ocasiones alcanzaban la parte central de la pared, por lo general dividida en compartimentos. El mármol moteado quedaría reservado para habitáculos no especialmente señeros, por ser el más fácil de imitar, mientras que el veteado y sobre todo el brocatel se empleaban en las decoraciones de las estancias preeminentes (Abad, 1977-78, 189). A su vez, cuando se imitaban incrustaciones, se representaban piezas o tiras marmóreas, recortadas en distintas figuras geométricas y combinándolas conforme a algún dibujo. Dentro de estas últimas, M. Rostovtzeff $(1919,149)$ distingue dos estilos: uno «estructural helenístico» y otro de procedencia oriental (alguno de estos modelos estilísticos tuvieron larga vida, perdurando hasta fechas muy tardías, por lo que los traemos aquí a colación, al estar aún vigentes cuando se redecoró Puente de la Olmilla). Todas ellas están insertas en paneles rectangulares, con bandas de encuadramiento de diverso color, a modo de taracea. El motivo predominante es el rombo con un círculo central inscrito en un rectángulo. Este esquema compositivo se difundió ampliamente durante los siglos III y IV d.C. A esta última centuria pertenecen algunas estancias pintadas con incrustaciones en forma de círculos y rombos comprendidas en el interior de paneles rectangulares en la villa de El Ruedo (Hidalgo, 1990, 116-117 y 119). Ese mismo tipo de decoración es el que más abunda en Mérida (Abad, 1977-78, 192, 194197, 202; 1982, 304). Las imitaciones de mármoles, representadas ya en las pinturas del I estilo (Barbet, 1985), fueron muy apreciadas durante la Antigüedad Tardía, por lo tanto, cuentan con una dilatada tradición, con gran profusión a lo largo y ancho del Imperio (un extenso inventario de edificios donde hay testimonios pictóricos nos brinda Abad, 1977-78, 189-208; a algunos otros hacen mención Borda, 1958, 135-141 y Álvarez Sáenz de Buruaga, 1974, 182-183). Este último investigador las considera propias de los siglos III y IV d.C., pese a tener un origen más antiguo. Esa misma datación es atribuida por M. R. Puig (1979, 924) a las pinturas de Puente de la Olmilla y aunque ya se conocía anteriormente ese tipo concreto de ornamentación pintada (esta misma autora [Puig, 1977, 869$870]$ ha constatado su uso en Clunia, en decoraciones pictóricas más tempranas, de los siglos I-II d.C.), es en época bajoimperial cuando tuvo una mayor difusión, perviviendo incluso hasta el siglo $\mathrm{V}$, como se acredita en la basílica paleocristiana conservada en el Museo de Historia de la Ciudad de Barcelona (Abad, 197778, 203-204).

Desde luego, los coloridos paneles que ornaban la galería desarrollada en torno al patio central (n. ${ }^{\circ} 6$ ), las imitaciones de mármol moteado, etc., están en consonancia con el gusto predominante en la pintura del siglo IV d.C.

Los ejemplos analizados, a partir de los restos conservados en Puente de la Olmilla, demuestran que se decoró algunas paredes de esta villa (p. ej., las del peristilo) con un esquema basado en una división tripartita muy usual en el mundo romano: la parte inferior (I) se subdivide en un rodapié o plinto de estuco pintado y un zócalo de imitación marmórea, consistente en una sucesión de paneles policromos divididos por líneas verticales negras, si bien en otras ocasiones no estaba compartimentado, sino que era continuo, simulando un mármol moteado o presentando ocasionalmente una decoración de bandas de contrastada coloración; 
más arriba, el sector medio (II), separado del zócalo por un ancho trazo negro o rojo y negro..., pudiendo vislumbrarse escasos restos pictóricos de diferentes tonalidades; finalmente la zona más alta (III), rematada por una cornisa moldurada en estuco, en contacto con el techo.

En cuanto a su técnica, únicamente sabemos que las pinturas tenían dos capas preparatorias, cuyo espesor no sobrepasaba los $5 \mathrm{~cm}$ en total. En este sentido, no se siguió los consejos de Vitruvio (De Arch. VII, 3), que recomendaba aplicar al muro un revestimiento compuesto de siete capas, ni las sugerencias de Plinio (NH XXXVI, 23), que proponía reducirlas a cinco. En la pintura provincial suele observarse la existencia de tres capas previas, de lo que cabe deducir que el trabajo de los artesanos no se ajustaba tanto a las directrices teóricas de los autores clásicos como a su experiencia cotidiana (los ejemplos conocidos no suelen avenirse a esas pautas, que, por otro lado, y dada la distancia cronológica, en el transcurso del tiempo habrían sido ya olvidadas). M. R. Puig $(1979,925)$ supone que «el mortero estuvo adherido a la pared (...) mediante incisiones o golpes en la misma». Con ello se lograría una mejor sujeción del mismo (acerca de los procedimientos de preparación de las paredes en la pintura mural romana, cfr. Allag y Barbet, 1972).

El estucado es, en definitiva, una de las principales artes decorativas romanas aplicadas a la construcción $\mathrm{y}$, en el caso de la villa objeto de nuestra atención, ejemplifica perfectamente el grado de desarrollo alcanzado por esta técnica.

Los diferentes sistemas ornamentales (pictórico, musivario, arquitectónico...) se suceden en la decoración de algunos ambientes, acentuando su importancia y distinción. No era inhabitual la existencia de un programa unitario, elaborado conjuntamente por arquitectos, estucadores, pintores y mosaístas, que se adecuaban a la moda vigente, si bien a veces no trabajaban de forma coordinada, sino separadamente (Guiral y Mostalac, 1993, 365-392; sobre los talleres dedicados a la pintura, integrados por artesanos especializados, cfr. Regueras, 2013, 98-100; Guiral, 2014, 105-126, con bibliografía actualizada). Todo ello servía de manifestación de los gustos estéticos y posición económica del dominus.

\section{CRONOLOGÍA DE LA VILLA}

La secuencia estratigráfica documentada en este yacimiento es la siguiente:

- unos $40 \mathrm{~cm}$ de tierra vegetal

- una capa de tejas, entremezcladas con algunas piedras, restos de estuco con decoración pintada, cerámica... (nivel de colmatación)

- el nivel de suelo (terrizo o bien pisos de argamasa o de mosaico).

Únicamente se excavó bajo los pavimentos musivos de las habitaciones 1 y 2 , una vez fueron extraídos.
Al profundizar por debajo de la cota del piso se descubrió un nivel de relleno consistente en tierra muy fina, cribada, mezclada con abundante arena, algún adobe y piedras. Lo más relevante de su material arqueológico, típico de un relleno, era alguna cerámica con una cronología del siglo I d.C.-principios del II, lo que denota la existencia de una fundación de esa época. A tenor de un fragmento $24 / 25$ de TSH, al que se hace referencia en el Diario de excavación del año 1975, algunas muestras de la cultura material de esta UE pueden adscribirse al siglo I d.C. Merece destacarse especialmente un fragmento de TSG con el sello OF. VITA (del que no disponemos de un dibujo o fotografía, ni nos ha sido posible localizarlo entre los fondos del Museo Provincial de Ciudad Real, siéndonos conocido tan sólo por una breve noticia de Puig y Montanya, 1975, 140). Según los excavadores, en el nivel arqueológico asociado a esos fragmentos cerámicos no apareció ninguna estructura.

Entre el variado, aunque exiguo y muy fragmentado material arqueológico proporcionado por los trabajos de excavación practicados en Puente de la Olmilla (monedas, vajillas de mesa, objetos de metal...), cabe mencionar por su significación dichas cerámicas de los siglos I-II d.C. y varias piezas monetales coetáneas, que confirman la existencia de un primer establecimiento altoimperial. Por otro lado, algunas secciones del complejo arquitectónico cuyas ruinas hemos sacado a la luz fueron erigidas ex novo durante el siglo IV d.C. Pudo ocurrir que, al ser entonces este lugar objeto de una reocupación, la villa hubiera sido reconstruida sobre la base de la edificación precedente, algunas de cuyas estructuras estarían tal vez subsumidas bajo las tardoimperiales, algo difícilmente perceptible hoy día. A modo de hipótesis, si bien aquélla podría estar medio derruida al haber quedado deshabitada durante un lapso de tiempo considerable y se hubieran rehabilitado total o parcialmente algunas de sus dependencias en el siglo IV, tampoco puede descartarse que esa instalación anterior hubiera sido desmontada expresamente, en mayor o menor medida, para levantar parte de esta otra de nueva planta, utilizándola como cantera, mediante el desmantelamiento de los elementos pétreos, latericios, etc.

Son numerosos los ejemplos de villae en las que hay vestigios de varias etapas de habitación. Por poner un ejemplo a modo ilustrativo, en la de Liédena hubo dos conjuntos residenciales superpuestos. El superior aprovechó algunos muros del subyacente. A tal efecto, se allanó los escombros, en vez de vaciarlos, además, se «conservó la orientación y trazado general del edificio, yuxtaponiendo muros nuevos a los destruidos, o, con más frecuencia, elevando otros paralelos y próximos a los antiguos» (Blázquez y Mezquíriz, CMRE VII, 1985, 28). Algo similar a esto último pudo haber sucedido en Puente de la Olmilla, p. ej., en el sector noroccidental (ambientes n. ${ }^{\circ} 24,26,28,29 \ldots$ ).

De hecho, en este yacimiento se han detectado dos niveles ocupacionales y, dentro de éstos, se han 
registrado, al menos, cuatro fases constructivas diferentes. El nivel más antiguo documentado arranca en la primera centuria d.C. Evidencias de esa época de fundación son las muestras numismáticas y los escasos fragmentos cerámicos a los que hemos hecho alusión. Tras ese momento inicial parece haberse producido un paréntesis en su habitación, un vacío que dio paso a un periodo de gran reactivación. Así pues, la planta definitiva de la villa se habría configurado en el transcurso del siglo IV d.C., aunque probablemente hubo una reutilización de algunas estructuras de la primitiva unidad doméstica.

$\mathrm{Su}$ época de máximo florecimiento se enmarca cronológicamente en torno a la segunda mitad de esa centuria, a la que pertenece la interesante colección de mosaicos aplicada a la ornamentación de algunos suelos, cuya datación estilística complementa la de buena parte del material cerámico y numismático. En cuanto a este último, el conjunto contiene numerario de cronología muy dispar ${ }^{7}$. Su intervalo temporal es superior a los cuatrocientos años, siendo el 12 a.C. la fecha de la pieza monetal más antigua, un as de Carthago Nova, en tanto que las más modernas son un centenionalis de Honorio, del 393-395 d.C., otro centenionalis del 394395 d.C., emitido posiblemente durante el reinado de Arcadio, Honorio o Teodosio II, y un minimus, del siglo V. Asimismo, hay cuatro ejemplares acuñados entre los siglos I-II d.C. (en el 72 ó 77-78, del 98 al 117, del 140 al 144 y del 140 al 192 d.C., respectivamente), y cuatro del siglo III (cuyas emisiones abarcan desde el 251 al 253, del 257 al 259, el 266 y el 269 d.C.), aunque no creemos que esas monedas nos remitan a una ocupación de este emplazamiento durante el siglo I a.C., sino, más bien, a una prolongada circulación de las mismas, dado su gran desgaste y la ausencia de otros elementos arqueológicos coetáneos asociados (a propósito de «las valoraciones circunstanciales» de los hallazgos monetarios y la prudencia aconsejable a la hora de «extraer conclusiones históricas» de los mismos, «más allá de las fechas de emisión de cada serie», cfr. Abascal, 1995, 153-154). Este investigador pone de relieve que en diversos lugares de Europa occidental (la Galia, Conimbriga, Baelo Claudia, La Olmeda...) y del Norte de África, al menos hasta el año 330 d.C. se atestigua la presencia de radiados del siglo III en estratos bien datados en el siglo IV d.C., renovándose progresivamente con las series emitidas bajo el gobierno de la familia de Constantino, e incluso hace un repaso de varios tesorillos de principios del siglo IV que contienen bronces del siglo I d.C., sestercios, antoninianos, etc. (Abascal, 1995, 149, 156-157, notas $63-69$; 157, nota 70). En multitud de yacimientos se ha podido comprobar que durante el Bajo Imperio se mantienen en circulación con carácter «residual» (denominación objeto de debate, como aduce Abascal,

7. Cuyo estudio pormenorizado daremos a conocer en el próximo número de la revista Numisma.
1995,156 , nota 53) especies ya obsoletas, sobre todo «en momentos de carencia en el abastecimiento o de alteración (...) de la ley de emisión» (Abascal, 1995, 144, 149, 156, nota 63). Al hilo de estos argumentos, se puede explicar la pervivencia de acuñaciones más antiguas en los circuitos del siglo IV d.C., lo que, a juicio de J. M. Abascal, conlleva replantearse la utilización, de forma aislada, del numerario como indicador cronológico de datación absoluta. Siguiendo esa línea interpretativa, las monedas del siglo III recuperadas en Puente de la Olmilla estarían en circulación junto a las del siglo IV, que constituyen un núcleo de nueve o posiblemente diez. Es de notar que el porcentaje más alto corresponde al siglo IV d.C.: tres a la primera mitad y seis (o quizás siete) a la segunda.

Durante la intervención arqueológica y la prospección de los contornos encontramos algunos ejemplares de TSHt y TSCD, que corroboran una datación tardía.

La cerámica doméstica de este yacimiento no tiene valores muy significativos y aún mayor parquedad presentan los fragmentos adscribibles a la tipología de terra sigillata. En efecto, los restos de vajilla fina de mesa son muy escasos, incluso podríamos decir, pobres, sobre todo comparados cuantitativamente con los de otro yacimiento que hemos estudiado, el de la Plaza del Torreón, con el que tampoco es en absoluto equiparable el volumen de fragmentos de cerámica común hallados, considerablemente mayor en el de Alcázar de San Juan. En palabras de algunos investigadores, la presencia, «en el caso de las cerámicas de lujo, en otro asentamiento puede significar una situación no de excepcionalidad, sino de norma y de objetos de la vida cotidiana» (Cerrillo et alii, 1986, 133). En cambio, la terra sigillata sí pudo constituir un producto de prestigio en este enclave de Puente de la Olmilla, quizás adquirido muy minoritariamente, aunque la circunstancia de su probable abandono paulatino ha debido de influir, sin duda, en su exigua presencia en el registro arqueológico, por lo que no es un argumento definitorio. Tal vez la demanda de esta clase de cerámica no fue realmente tan reducida como podría deducirse $a$ priori, pero no podemos pasar por alto que los vestigios conservados son pocos.

Dichas producciones, asociadas a diferentes momentos cronológicos de la evolución de la villa, sobre los que ilustran con claridad, corresponden a los dos niveles de ocupación de Puente de la Olmilla, pero la mayoría apunta al siglo IV d.C. No obstante, como ya hemos señalado, se han podido reconocer algunas altoimperiales, p. ej., las aparecidas al excavar bajo la cama del mosaico de la habitación $\mathrm{n}^{\mathrm{o}}$ 1, que nos sirven para fechar la primera fase del asentamiento con bastante certeza.

Destacan en Puente de la Olmilla algunas buenas producciones de TSH. Entre los diferentes tipos formales, contamos con algunos ejemplos de los estilos decorativos característicos de la TSH y TSHt, que, relativamente hablando, es la más numerosa. Estas cerámicas están representadas por una serie de fragmentos 
que nos permiten reconstruir diversas formas, como la $8,17,27,33,36,37,40 \ldots$ Esos ejemplares, correspondientes a piezas cerámicas fabricadas en figlinae de Andújar, de La Rioja e inclusive otras procedentes de talleres africanos, ponen de manifiesto la existencia de relaciones con diversos centros productores de un amplio radio geográfico y la integración de este territorio en los canales comerciales del Imperio, a través de los que fueron importadas, procedentes incluso de lejanos mercados urbanos. Este origen foráneo abona la idea de que pudieran ser consideradas cerámicas de prestigio. En buena medida, la TSH parece proceder de alfares de Andújar, al igual que algunas piezas de cerámica común (morteros estriados...). También se ha documentado un tipo de cerámica fina decorada a la ruedecilla, propio de la zona de Oreto y Castulo.

En suma, la cultura material mueble e inmueble, mayoritariamente, lleva a inscribir la plenitud de esta villa en un momento avanzado del siglo IV. Como ya expusimos, la decoración pictórica y musiva presenta unas características propias de esa etapa tardía ${ }^{8}$. Sus aspectos compositivos son propios de ejemplares bajoimperiales (cfr. García Bueno, 1994, 95-116, donde ofrecemos una amplia relación de paralelos formales de los pavimentos de mosaico).

En lo referente a su fecha final, estuvo en uso, cuando menos, hasta comienzos o primeras décadas del siglo V (o algo más adentrado éste), tal como sugieren algunos fragmentos cerámicos y las citadas muestras monetales más recientes: tres centenionales, cuya cronología ronda entre el 388 y el 395 d.C. (uno de los cuales tiene un alto grado de desgaste), y el minimus, del $\mathrm{V}$, que marcan por ahora el término post quem. Lo delatan también ciertas alteraciones que sufrió la planta en el curso de los años, algunas de las cuales afectaron a los pisos en opus tessellatum de la segunda mitad del siglo IV. Hubo, pues, actividad edilicia hasta época bastante tardía. Los sondeos han puesto de manifiesto la existencia de varias obras de ampliación, la compartimentación interna de algunos espacios, distintas capas de pintura aplicadas sucesivamente sobre las paredes, el recubrimiento de algunas superficies parietales con nuevos paneles de estuco pintado y varias remodelaciones de mayor o menor cuantía llevadas a cabo en diversos puntos del edificio solariego, que no supusieron una transformación completa del mismo, pues en lo sustancial se mantuvo su esquema original, aunque sí experimentó una renovación significativa de algunas de sus estructuras y de su programa decorativo. En ocasiones, esas modificaciones dejaron un rastro muy nítido, así, se puede observar en algún pavimento y lindando con los lienzos musivos el arranque de la base preparatoria de las pinturas murales que cubrían

8. Algunas de las cuales exponemos en un trabajo aún inédito: «Un nuevo mosaico de los Cuatro Vientos, en la villa de Puente de la Olmilla (Albaladejo, Ciudad Real)», en Actas del XIII Congreso de la AIEMA (sept. 2015). los tramos de muro seccionados a posteriori con el propósito de efectuar la abertura de algunos vanos (p.ej., entre las habitaciones 15 y 16). Esas reformas y yuxtaposiciones, acometidas en diferentes momentos del periodo en que fue habitada esta unidad doméstica, reflejan una evolución de las necesidades y gustos de sus impulsores -los propietarios-, a los que se fueron adaptando. De acuerdo con todo ello, se sucederían varias generaciones de inquilinos en el devenir de la villa. Terminados los tiempos de esplendor de este enclave, es evidente un paulatino proceso de decadencia. Buena prueba de ello es la tosca refectio de los mosaicos deteriorados por el desgaste cotidiano, reveladora de una incapacidad de los operarios locales para imitar la calidad artística de la officina que los elaboró. Debieron de sufrir sucesivas reparaciones, hasta un momento muy cercano al de la caída en desuso de la villa. Conforme se fueron erosionando ya no se encargó a unos artesanos tessellarii la reposición de las teselas que faltaban, sino que lo hicieron manos inexpertas, como queda patente en el intento de recomponer, con una completa falta de destreza, uno de los temas ornamentales del mosaico de la habitación n. ${ }^{\circ} 1$ (imitando torpemente los eslabones, Fig. 20), o en el pasillo n. ${ }^{\circ} 11$, que fue objeto de alguna restauración de pequeña entidad, igualmente con un resultado poco logrado, al romper el diseño ese pretendido «arreglo» con teselas blancas. La pavimentación musiva fue reparada sin mucho cuidado tras la realización de alguna obra o bien como relleno de calvas producidas al degradarse el material original a consecuencia del constante trasiego, sobre todo en los deambulatorios, y para ello se procedió a «parchear» las lagunas con una capa de argamasa u ocasionalmente se sustituyeron las teselas de los motivos decorativos malogrados por grupos de teselas blancas e incluso eventualmente se suplieron con un ladrillo, en un tramo muy dañado (pasillo n. ${ }^{\circ}$ 5). Sería durante la ocupación más tardía cuando se debió de colocar ese ladrillo y se enmendó otros desperfectos con mortero de cal; ya ni tan siquiera se procuró reintegrar con nuevas teselas las que se iban perdiendo, como se había ido haciendo con anterioridad, síntoma inequívoco de una continuidad del funcionamiento de la villa hasta fechas avanzadas, inmersa en su declive. Distinguimos, por tanto, dos fases en la manera de subsanar esos fallos.

Todas estas circunstancias caracterizan la última etapa de la vida de este complejo rural, en su ocaso, cuando, pese a las dificultades, se hizo lo posible para mantener un nivel aceptable de confort.

No se aprecian signos importantes de devastación, salvo de la lenta e inexorable acción destructora del tiempo. De ello se infiere el abandono pacífico del lugar, producido quizás de forma progresiva a partir de inicios del siglo $\mathrm{V}$, si bien ciertos cambios estructurales y algunos materiales arqueológicos (p. ej., atendiendo al grado de conservación de algunas de las monedas más recientes, que muestran gran pérdida de relieve, al estar muy desgastadas) apuntan a que pudiera haberse dilatado algo más a lo largo de esa centuria, 


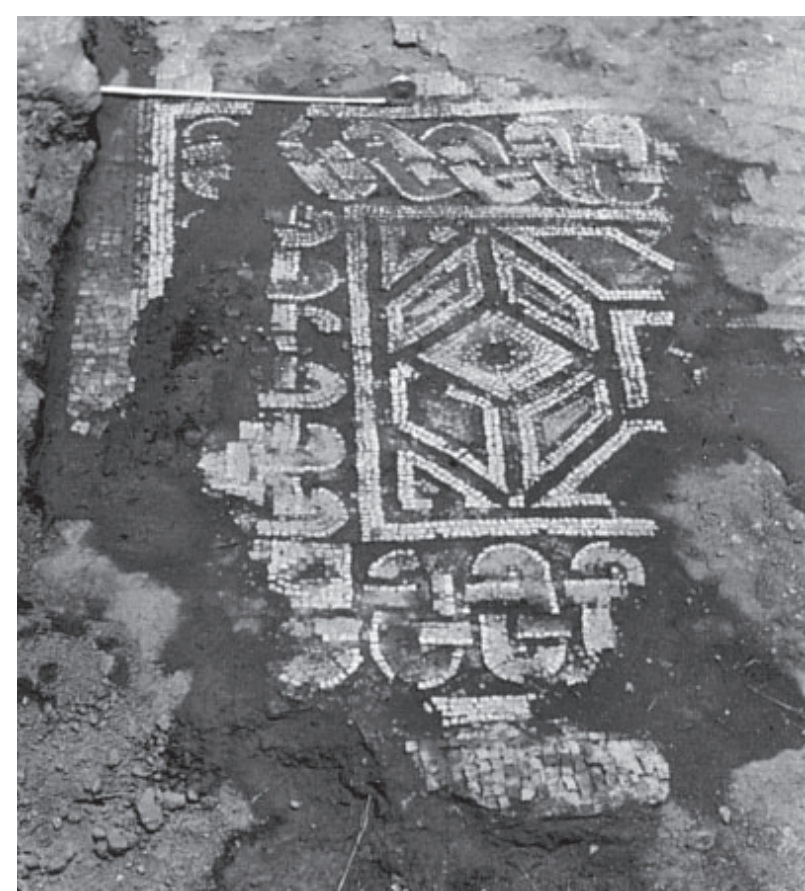

Figura 20: Detalle de uno de los tapices subordinados del pavimento musivo de la habitación $\mathrm{n}^{\circ}{ }^{\circ} 1$, donde se aprecian las diferencias entre algunos eslabones de la cadena circundante, probablemente fruto de una reelaboración posterior. Foto: Puig y Montanya (AGA).

como ya se ha dicho, sin que podamos definirlo con mayor precisión, pues el cese de los hallazgos de nuevas producciones cerámicas o monetarias no implica forzosamente la interrupción de la dinámica histórica de este asentamiento, ni de su actividad económica (p. ej., el aporte de numerario disminuyó radicalmente entonces, al igual que en todo el Imperio de Occidente). Quienes lo habitaban no parecen haberse marchado de forma rápida ni precipitada, dada la exigüidad de cerámicas, utensilios u otros objetos encontrados (casi nunca enteros), que seguramente abundarían más de haber sido así. Por consiguiente, todos los testimonios arqueológicos revelan que la villa fue abandonada sin violencia, no arrasada intencionadamente, al no advertirse señales claras de destrucción, salvo la provocada por el fuego, que le afectó sólo parcialmente. Probablemente no todo el edificio sufrió un incendio generalizado, en cuyo caso el tejado habría caído entero envuelto en llamas, de lo que no hay pruebas en el registro material. La mayoría de las veces las evidencias de combustión consisten en bolsadas de tierra cenicienta, aunque en determinadas zonas, al quemarse puntualmente el entramado de vigas de la techumbre, ésta se vino abajo, desplomándose sobre el suelo el maderamen y las tejas, mezclados con otros materiales de derrubio. Parece tratarse de episodios esporádicos y muy restringidos: en el pórtico exterior documentamos cenizas asociadas a huesos de cérvidos u otras especies animales comestibles, conchas de molusco... (los restos de una hoguera); en algunas habitaciones, como la 2, la 12 o la 35 , estaban entremezcladas con huesos de fauna diversa, ostras y una rueda de molino; en la puerta de comunicación entre los ambientes 39 y 31 había algunas cenizas bajo el nivel de derrumbe, también en los pasillos 3 y $32 \ldots$ En cambio, en el patio sí se acreditó la existencia de un potente nivel de incendio. Entre esa densa capa de carbones, cenizas y tejas recuperamos dos monedas de Galieno, respectivamente del 266 y del 269 d.C., y otra de Constancio II, fechada entre 335-341 d.C., junto a restos óseos de animales vertebrados e invertebrados (valvas de moluscos...). Pudiera ser que el foco del fuego estuviera en una hoguera encendida en dicho patio, que se habría extendido a la galería circundante. Sin embargo, en ninguno de los muros pétreos del conjunto doméstico hay huellas de calcinación, tan sólo unos fragmentos de pintura quemada en el corredor $n .^{\circ} 32$. Algunos de los suelos de opus caementicium quedaron destrozados al caerles encima, de golpe, los elementos de cubrición, p. ej., en las habitaciones n. 30 y 39, pero al ser excavadas no aparecieron sepultadas bajo el nivel de derrumbe piezas cerámicas completas (esto es, rotas in situ), ni una gran cantidad de enseres u otros restos mobiliares. De ello podría deducirse que los últimos dueños se llevaron consigo todo cuanto pudiera serles de utilidad.

Tampoco tenemos una rigurosa constancia arqueológica de que después de esa fecha de cierre hubiera una reocupación de la vivienda señorial por parte de una población de carácter residual, si bien es muy posible que pastores o gentes de paso pudieran haber buscado cobijo en ella esporádica o temporalmente, por consiguiente, ese reaprovechamiento habitacional habría tenido un carácter poco estable (entra dentro de lo razonable pensar que existió ese reaprovechamiento, pero presumiblemente pudo ser bastante breve, al menos de acuerdo con la ausencia de otros indicios de que la casa siguiera estando habitada, más allá de servir de refugio transitorio). El encendido de hogueras para calentarse o cocinar podría explicar el calcinamiento de algún tramo de pavimento musivo, no obstante, éste puede ser simplemente el resultado de un incendio fortuito que hizo desplomarse una parte de la cubierta sobre el piso de mosaico (pasillo n. ${ }^{\circ} 3$ ). En todo caso, no creemos que se deban interpretar las manchas cenicientas como las secuelas de un hecho violento, sino una consecuencia de esas hogueras mencionadas líneas arriba o una manifestación más del lógico deterioro producido paulatinamente tras el abandono definitivo, sin relación con una presencia humana.

La Carthaginiensis, como toda la Tarraconensis, fue partidaria de Honorio, en tanto que otras provincias se adhirieron a Constancio III. Se generó entonces una sensación de inseguridad en Hispania, con la que tal vez pueda ponerse en relación ese abandono final de esta villa.

J.-G. Gorges (1979, 43-44, 150-151) cree que centenares de villae hispanas fueron asoladas por los invasores germanos y lo pone en relación con ciertos elementos (torres...), que tendrían un carácter defensivo 
(véase las discrepancias al respecto de A. Chavarría, 2007, 104-108). Pese a esos supuestos intentos de fortificarse, muchas de ellas habrían sido saqueadas, lo que marcaría «la época de desaparición o abandono de la mayoría de las villas». Sin embargo, realmente no son pocas las que persistieron en los siglos $\mathrm{V}$ y VI.

Numerosos autores defienden la idea de que muchos de estos establecimientos rurales fueron deshabitados a causa de la situación de peligro provocada por las incursiones bárbaras (Cerrillo, 1995, 3; Vaquerizo y Noguera, 1997, 35), por el bandidaje, las depredaciones de los bagaudas (Hidacio, Chron. 125, 141; Mamertino, Pan. Lat. II,4,5; Oros., Hist. adv. pag.; Salviano, De gub. Dei V,VI,24) o por los levantamientos de siervos contra sus propios señores, que no se pueden identificar propiamente con el movimiento bagáudico (Aug., Epíst. 108). En contraposición a dicho enfoque, al decir de otros especialistas en la materia, como J. M. Blázquez (1986, 471-472): «la vida continuó en muchas villas como antes, al margen de los acontecimientos bélicos, que seguramente no fueron tan catastróficos como una lectura de Hidacio supone». Basándose en el estudio de la musivaria hispana, pone en duda que fueran tan generalizadas las destrucciones a manos de los invasores bárbaros descritas por este cronista. Como él, muchos otros estudiosos del tema dan por superada esa imagen de caos y devastación (Chavarría, 2007, 69-77, 158; Regueras, 2013, 151-154). Las tendencias historiográficas actuales dudan de la veracidad de «relatos apocalípticos» como el de Hidacio.

Desde luego, el fenómeno que quizás pudo provocar el colapso de numerosas villae a finales del siglo IV o a lo largo de la siguiente centuria, no encuentra apoyo en el registro arqueológico de Puente de la Olmilla, a no ser desde la perspectiva de esa supuesta sensación de inseguridad que pudieron sentir sus habitantes (el miedo a los bandidos es reflejado por Symmaco [Epist. 2,22 a. 382]; sobre las luchas en Hispania antes de las invasiones de suevos, vándalos y alanos, cfr. Blázquez, 2009, 618-622; en lo que respecta al asunto de la inseguridad y el abandono de las villae, cfr. Arce, 2006, 14-15).

Por último, es de subrayar que, pese a haber aparecido en Puente de la Olmilla algunos fragmentos cerámicos contemporáneos e incluso una moneda del reinado de Isabel II, no están asociados a restos constructivos coetáneos. Al menos, a la luz de lo descubierto hasta ahora, ninguna estructura se superpone al hábitat romano, que se encontraba sellado por la unidad de abandono. Esas intrusiones son consecuencia del laboreo agrícola, que ha ocasionado ciertas alteraciones estratigráficas en el yacimiento. No hubo, por lo tanto, una perduración del poblamiento en este mismo paraje geográfico.

Carmen García Bueno

C/ Sta. Ana, 15, $3^{\circ}$

13500 Puertollano (Ciudad Real)

carmengbueno2014@gmail.com

\section{ABREVIATURAS}

AGA: Archivo General de la Administración

AIEMA: L'Association internationale pour l'étude de la mosaïque antique

JCCM: Junta de Comunidades de Castilla-La Mancha

TSC: Terra Sigillata Clara

TSHt: Terra Sigillata Hispánica tardía

\section{BIBLIOGRAFÍA}

Abreviaturas empleadas

AAC: Anales de Arqueología Cordobesa AEspA: Archivo Español de Arqueología

CIL: Corpus Inscriptionum Latinarum

CMGR: Colloque. La Mosaïque Gréco-romaine

CMRE: Corpus de Mosaicos Romanos de España

JHS: Journal of Hellenic Studies

MCV: Mélanges de la Casa de Velázquez

ME: El Miliario Extravagante

ABAD CASAL, L., 1977-78: «Las imitaciones de crustae en la pintura mural romana en España», AEspA, L-LI, 189-208.

ABAD CASAL, L., 1982: La pintura mural romana en España, Alicante-Sevilla.

ABASCAL PALAZÓN, J. M., 1995: «Hallazgos arqueológicos y circulación monetaria. Disfunciones metodológicas en el estudio de la Hispania romana», en Actas del IX Congreso Nacional de Numismática (Elche, 1994), 143-158, Elche.

ADAM, J.-P., 1984: La construction romaine. Materiaux et techniques, París.

ADAM, J.-P., 1996: La construcción romana, materiales y técnicas, León.

ALLAG, C. y BARBET, A., 1972: «Technique de préparation des parois dans la peinture murale romaine», Mélanges de l'École Française de Rome, Antiquité, 84.

ALFÖLDY, G., 1999: «Aspectos de la vida urbana en las ciudades de la Meseta sur», en J. González (ed.), Ciudades privilegiadas en el Occidente romano, 467-485, Sevilla.

ALFÖLDY, G., 2012: Nueva historia social de Roma, Sevilla.

ALMAGRO BASCH, M., 1978: Segóbriga. Guía del Conjunto Arqueológico, Madrid.

ÁLVAREZ SÁENZ DE BURUAGA, J. A., 1974: «Una casa romana, con valiosas pinturas, de Mérida», Habis 5,169-187.

ARCE MARTÍNEZ, J., 2006: «Villae en el paisaje rural de Hispania romana durante la Antigüedad tardía», en A. Chavarría, J. Arce y G. P. Brogiolo (eds.), Villas Tardoantiguas en el Mediterráneo Occidental, Anejos de AEspA XXXIX, 9-15, Madrid.

ARCE MARTÍNEZ, J., 2009 (2ª ed.): El último siglo de la España romana, Madrid.

ARIAS BONET, G., 1963: «Miaccum, Toletum, Titultiam, Complutum», $M E$, 2, 29-33, París. 
ARIAS BONET, G., 1968: «Sobre la longitud de la milla en la Hispania romana», $M E, 14,391-394$, París.

ARIAS BONET, G., 1987: Repertorio de caminos de la Hispania romana, La Línea.

ARIAS BONET, G., 1991: «Una visión de las vías hispanas meridionales», $M E$, 35, 8-9, París.

ARIAS BONET, G., 1992: «Índice de mansiones y ciudades de la Hispania romana», $M E$, 41, 7-19, La Línea.

ASÍN Y PALACIOS, M., 1940: Contribución a la toponimia árabe de España, Madrid.

AYALA MARTÍNEZ, C. de, 1996: «Las Órdenes militares y la ocupación del territorio manchego (s. XII-XIII)», en R. Izquierdo Benito y F. Ruiz Gómez (coords.), Actas del Congreso Internacional Conmemorativo del VIII Centenario de la Batalla de Alarcos, 47-104, Ciudad Real.

BARBET, A., 1983: «Quelques rapports entre mosaïques et peintures murales à l'époque romaine», Mosaïques. Recueil d'hommages à Henri Stern, 43-53, París.

BARBET, A., 1985: La peinture murale romaine. Les styles décoratifs pompéiens, París.

BARBET, A., 1990: «L'emploi des couleurs dans la peinture murale romaine antique», en Pigments et colorants de l'Antiquité au Moyen Age. Teinture, pinture, enluminure, études historiques et physcochimiques, 255-271, París.

BENDALA GALÁN, M., 1992: «Materiales de construcción romanos: peculiaridades de Hispania», en Ciencias, metodología y técnicas aplicadas a la arqueología, 215226, Barcelona.

BENDALA, M., RICO, CH. y ROLDÁN, L., 1996: El ladrillo y sus derivados en la época romana, Madrid.

BENÍTEZ DE LUGO ENRICH, L. (coord.), 2011: «Villae en el municipium de Mentesa Oretana. Termas romanas y necrópolis tardo-romana en La Ontavia (Terrinches, Ciudad Real). Resultados de la investigación y proyecto de musealización», Herakleion 4, 69-125.

BENÍTEZ DE LUGO ENRICH, L., 2012: «Estudio arqueológico en la Vía de los Vasos de Vicarello, A Gades Romam, entre las estaciones de Mariana y Mentesa (Puebla del Príncipe-Villanueva de la Fuente, Ciudad Real)», AEspA, 85, 101-118.

BLÁNQUEZ PÉREZ, J., 1990: «La Vía Heraklea y el camino de Aníbal. Nuevas interpretaciones de su trazado en las tierras del interior», en Simposio sobre la red viaria en la Hispania romana, 65-76, Zaragoza.

BLÁZQUEZ MARTÍNEZ, J. M., 1986: «Mosaicos hispanos de la época de las invasiones bárbaras. Problemas estéticos», Antigüedad y Cristianismo III, 463-489, Murcia.

BLÁZQUEZ MARTÍNEZ, J. M., 2009: «Villas fortificadas en la Hispania del Bajo Imperio», Limes $X X, X X$ Congreso Internacional de Estudios sobre la frontera romana (León, 2006), Anejos de Gladius 13, II, 615-629, Madrid.

BLÁZQUEZ MARTÍNEZ, J. M. y MEZQUÍRIZ IRUJO, M. A., 1985: Mosaicos romanos de Navarra, CMRE VII, Madrid.

BORDA, M., 1958: La pittura romana, Milán.

CARANDINI, A. ET ALII, 1982: Filosofiana: La Villa de Piazza Armerina. immagine di un aristocratico romano al tempo di Constantino, Roma.
CARRASCO SERRANO, G., 2013: «Las fuentes itinerarias y las vías romanas en la Meseta sur», Debita verba II. Estudios en Homenaje al Profesor Julio Mangas Manjarrés, 273-282, Gijón.

CERRILLO MARTÍN DE CÁCERES, E., 1995: «Reflexiones sobre las villae romanas en Hispania», en J. M. Noguera (coord.), Poblamiento rural romano en el Sureste de Hispania, Actas de las Jornadas celebradas en Jumilla del 8 al 11 de noviembre de 1993, 17-26, Murcia.

CERRILLO, E., CERRILlO, F. J., ONGIL, M. I., HERRERA, G. y ALVARADO, M., 1986: «Espacio doméstico y espacio de prestigio», Arqueología Espacial, 10, 121-134.

CHAVARRÍA ARNAU, A., 2007: El final de las villae en Hispania (siglos IV-VII d.C.), Bibliothèque de 1' Antiquité tardive 7, Thurnout.

CHOISY, A., 1873/1999: El arte de construir en Roma, Madrid.

CORCHADO SORIANO, M., 1969: «Estudio sobre vías romanas entre el Tajo y el Guadalquivir», AEspA, 42, 124-158.

CORCHADO SORIANO, M., 1971: Avance de un estudio geográfico-histórico del Campo de Montiel, Ciudad Real.

FERNÁNDEZ CASTRO, M. C., 1982: Las villas romanas en España, Madrid.

GARCÍA Y BELLIDO, A., 1979 (2a ed./1972): Arte romano, Enciclopedia Clásica I, Madrid.

GARCÍA BUENO, C., 1994: «Mosaicos de la villa romana de Puente de la Olmilla (Albaladejo, C. Real)», Veleia, 11, 95-116.

GARCÍA BUENO, C., 2000: «Problemática de la arqueología romana en la provincia de Ciudad Real: la villa de Puente de la Olmilla (Albaladejo)», en L. Benítez de Lugo Enrich (coord.), El patrimonio arqueológico de Ciudad Real, 191-203, Valdepeñas.

GARCÍA BUENO, C., 2001: «Apuntes para el estudio de los mosaicos de la villa romana de Puente de la Olmilla (Albaladejo, Ciudad Real)», Pátina, 10 y 11, 212-217.

GARCÍA BUENO, C., 2011: «Uso y disfrute del agua en la villa romana de Puente de La Olmilla (Albaladejo, Ciudad Real). El aprovechamiento hídrico en el Mundo Romano», Espacio, Tiempo y Forma, Serie II, 24, 449-472.

GORGES, J.-G., 1979: Les villas hispano-romaines. Inventaire et problématique archéologiques, París.

GUIRAL PELEGRÍN, C., 2014: «La decoración pintada en la Hispania romana, artesanos y talleres, en M. Bustamante Álvarez y D. Bernal Casasola (coords.), Artifices idóneos: Artesanos, talleres y manufacturas en Hispania, 105-126, Mérida.

GUIRAL PELEGRÍN, C., MOSTALAC CARRILLO, A. y CISNEROS, 1986: «Algunas consideraciones sobre la imitación del 'mármol moteado' en la pintura romana en España», Boletín del Museo de Zaragoza 5, 259-288.

GUIRAL PELEGRÍN, C. y MOSTALAC CARRILLO, A., 1993: «Influencias itálicas en los programas decorativos de cubicula y triclinia de época republicana y altoimperial en España. Algunos ejemplos representativos», Espacio, Tiempo y Forma, I, 6, 365-392. 
HERVÁS Y BUENDÍA, I., 1890/1914: Diccionario Histórico Geográfico de la provincia de Ciudad Real, Ciudad Real.

HIDALGO PRIETO, R., 1990: «Esquemas decorativos pictóricos de la villa romana de El Ruedo (Almedini1la, Córdoba)», Anales de Arqueología Cordobesa, 1, 109-124.

HOFFMAN, B., 1975: «Les materiaux de construction antiques en terre cuite», Les Dossiers de L'Archéologie, 9, 111-120.

LAVIN, I., 1963: «The Hunting Mosaics of Antioch and their Sources», Dumbarton Oaks Papers, 17, 178-286.

LUGLI, G., 1957: Tecnica edilizia romana con particolari riguardo a Roma e Lazio, Roma.

MENA MUÑOZ, P., 1988: «La época republicana en Castilla-La Mancha: inicios de la romanización (siglo III-I a.C.)», en Actas del I Congreso de Historia de CastillaLa Mancha IV, JCCM, 25-51, Talavera.

MONTANYA MALUQUER, R., 1977: «Contribución a la carta arqueológica de Ciudad Real. Prospecciones en Albaladejo y sus alrededores», XIV CNA, II (Vitoria, 1975), 1133-1142, Zaragoza.

MOSTALAC CARRILLO, A., 1992: «La pintura romana en Hispania. Estado de la cuestión», Anuario del Departamento de Historia y Teoría del Arte de la UAM, IV, 9-22.

NOVELLO, M., 2003: «Il ruolo dell apparato decorativo nella caratterizzacione funzionale dello spazio abitativo», en S. Bullo y F. Ghedini (eds.), Amplissimae atque ornatissimae domus (Aug., civ., II, 20,26): l'edilizia residenziale nella città della Tunisia romana, 356-360, Padua.

PÉREZ RUIZ, M., 2010: El culto doméstico en la Hispania romana. Provincias Baetica y Tarraconensis, Tesis Doctoral, Universidad Autónoma de Madrid.

PÉREZ RUIZ, M., 2012: «El valor del culto en el paisaje doméstico. El caso hispano», Antesteria, 1, 241-253.

PÉREZ RUIZ, M., 2014: Al amparo de los Lares. El culto doméstico en las provincias romanas Bética y Tarraconense, Anejos de AEspA LXVIII, Madrid.

PÉREZ VILATELA, L., 1997: «El uso de per en el Itinerario de Antonino, parte hispánica», $M E, 61,20-24, \mathrm{La}$ Línea.

PLAZA SANTIAGO, R., GARCÍA SANDOVAL, J., FERNÁNDEZ DÍAZ, A., MARTÍNEZ RODRÍGUEZ, A., PONCE GARCÍA, J. y RAMALLO ASENSIO, S., 2003-2004: «Las pinturas romanas de «La Quintilla» (Lorca): Restauración y montaje expositivo», Memorias de patrimonio, 7, 247-262.

PORTUONDO Y LORET DE MOLA, B., 1972: Catálogo Monumental Artístico-Histórico de España. Provincia de Ciudad Real, ed. facsímil del original de 1917, Madrid, Ciudad Real.

PUIG OCHOA, M.R., 1977: «Pintura romana de Clunia (Burgos)», XIV CNA (Vitoria, 1975), 869-870, Zaragoza.

PUIG OCHOA, M.R., 1979: «Pintura romana de Albaladejo», XV CNA (Lugo, 1977), 923-930, Zaragoza.

RAMALLO ASENSIO, S. ET ALII, 2005: «La villa romana de La Quintilla (Lorca, Murcia). Análisis de su programa decorativo y ornamental», IXe Colloque International sur l'étude de la Mosaïque antique et médiévale (l'AIEMA), vol. 2, 1001-1021, Roma.

REGUERAS GRANDE, F., 2013: Villas romanas del Duero. Historia de un paisaje olvidado, Valladolid.

RODRÍGUEZ MORALES, J., 1999: «Algunos topónimos camineros y las vías romanas de la Península», $M E$, 71, 2-8, La Línea.

RODRÍGUEZ MORALES, J., 2000: «Laminium y la Vía 29 del Itinerario de Antonino», ME, 73, 16-23, La Línea.

RODRÍGUEZ MORALES, J., 2003: «Algunos textos sobre la construcción de las vías romanas», $M E, 85,24-27$, La Línea.

ROLDÁN GÓMEZ, L., 1987: «Aproximación metodológica al estudio de la técnica edilicia romana en Hispania, en particular el opus testaceum», Lucentum, VI, 101-122.

ROLDÁN HERVÁS, J.M., 1975: Itineraria Hispana. Fuentes antiguas para el estudio de las vías romanas en la Península Ibérica, Anejo de Hispania Antiqua, Valladolid-Granada.

ROSTOVTZEFF, M., 1919: «Ancient Decorative WallPainting», JHS, 39, 144-163.

ROYO GUILLÉN, J.I., 2001: «El conjunto arqueológico de La Malena (Azuara, Zaragoza)», en VV. AA., La Antigüedad Tardía en Aragón, col. Mariano de Pano y Ruata 20, 46-57, Zaragoza.

RUIBAL, A., 1988: «El castillo de Albaladejo, ¿Villar de Casa Paterna?, un enclave medieval de origen romano», en Actas del I Congreso de Historia de Castilla-La Mancha $\mathrm{V}, 261-271$, Talavera.

SAAVEDRA, E., 1862/1967: Discursos leidos ante la Real Academia de la Historia (con la contestación de don Aureliano Fernández-Guerra y Orbe), Madrid.

SANTOS GENER, S., 1955: Memoria de las excavaciones del Plan Nacional realizadas en Córdoba (1948-1950). Informes y Memorias 31, Madrid.

SERRA RÁFOLS, J. DE C., 1952: La villa romana de la Dehesa de La Cocosa (Badajoz), Badajoz.

SILLIÈRES, P., 1977: «Le Camino de Anibal. Itinéraire des gobelets de Vicarello, de Castulo à Saetabis», $M C V, 13$, 31-93.

SILLIÈRES, P., 1990: «La búsqueda de las calzadas romanas: desde la foto-interpretación hasta el sondeo», en $L a$ red viaria de la Hispania Romana,411-430, Zaragoza,.

TOVAR, A., 1989: Iberische Landeskunde III/2. Tarraconensis, Baden-Baden.

VAQUERIZO GIL, D. ET ALII, 1994: Arqueología Cordobesa. Almedinilla, Córdoba

VAQUERIZO GIL, D. y NOGUERA CELDRÁN, J.M., 1997: La villa de El Ruedo (Almedinilla, Córdoba). Decoración escultórica e interpretación, Murcia.

VIÑAS MEY, C. y PAZ, R., 1971: Relaciones de los pueblos de España ordenadas por Felipe II - Ciudad Real, Madrid. 